\title{
Desde el gobierno corporativo a la responsabilidad de los administradores (I)
}

\author{
Ramón Múgica Alcorta \\ Profesor de Derecho administrativo \\ Universidad de Deusto
}

\begin{abstract}
Resumen: La reciente crisis económica ha puesto en el centro del debate el asunto de la responsabilidad de los administradores de las compañías. Las miradas se han vuelto hacia los principios de Buen Gobierno Corporativo, en los que se depositan muchas esperanzas como instrumento para evitar disfunciones empresariales y problemas macroeconómicos. Pero, a la vez, se cuestiona la eficacia del régimen legal relativo a la responsabilidad de los administradores. ¿Es adecuado, en la presente situación, agravar los deberes y las responsabilidades? ¿Cuál sería el grado óptimo de exigencia que garantizase un buen funcionamiento del sistema? Y en todo caso interesa plantearse aun si el Derecho es suficiente, o son necesarias una cultura y una ética en la gestión, y cómo, en su caso, atribuir algún grado de vinculación externa a los principios éticos. Ligado a lo anterior aún nos preguntamos si la cultura, la ética y el Derecho han de ser, en este campo del funcionamiento societario y los deberes de los administradores, locales o globales. La experiencia de los tribunales americanos ofrece pautas interesantísimas para hacer frente a los retos implícitos en lo que acaba de exponerse, e interesa analizar la posibilidad de su trasvase a otros ordenamientos.
\end{abstract}

Palabras clave: Gobierno Corporativo; crisis financiera y económica; responsabilidad de los administradores, business judgement rule; caso Caremark.

Abstract: One of the main consequences of the recent economic crisis has been the narrow focus the scope of the debate has had on the managers of companies. Principles of Good Corporate Governance and Best Practice Recommendations are eventually being perceived as the instrument with which corporate disfunction and macroeconomic problems could be avoided. Is it the moment to increase obligations and liabilities, specially regarding present situation? Which is the adequate degree of requirement that would ensure system's efficiency? Moreover, the role of law is being questioned, recalling the support of ethics and culture in management, henceforth linking somehow external liability and ethical principles. Connected to the latter it's not yet clear whether culture, ethics and law should be, in corporate and management duties, local or global. American courts' experience offer very interesting guidelines in order to deal with the previously exposed challenges, that could be transferred to other legal systems.

Key words: Corporate Governance, economic crisis, officers and directors liability, business judgement rule, Caremark decision. 
Sumario: I. Consideraciones preliminares.-II. Sobre Gobierno Corporativo.--III. La expansión del Buen Gobierno Corporativo.-IV. Crisis económica y gestión de riesgos.- - V. El despliegue temporal del programa del Gobierno Corporativo.-VI. Remodelando el régimen legal de los deberes y responsabilidades de los administradores.-VIII. El papel de los jueces. Un caso ejemplar. La sentencia Citigroup de la Corte de Delaware.-VIII. La regla del juicio de los negocios (o del buen juicio empresarial): business judgement rule.-IX. El caso y la decisión Caremark. $\mathrm{X}$. Continuará.

\section{Consideraciones preliminares}

Constituye este capítulo el primero de los dos que componen un trabajo que tiene por objeto analizar cuál podría ser la medida óptima de la exigencia de responsabilidades a los administradores de las sociedades mercantiles. En el título que precede hay, ciertamente, algo de ambigüedad. Ello es debido a que pretende significar dos ideas a la vez. En primer lugar, la exacerbación de la severidad del régimen aplicable a la actuación de los administradores en tiempos de crisis financiera y económica en general, como son los actuales; segundo, describe el arco máximo que puede recorrer la aguja de la responsabilidad de los administradores, acotado en un extremo por las previsiones de soft law (los principios de Gobierno o Buen Gobierno Corporativo) y en el otro por la determinación del Derecho positivo que prevé sanciones de distinta índole que, en el tramo superior de la escala, pueden llegar a tener una máxima gravedad, como sucede con las de naturaleza penal. No es ocioso, a este respecto, recordar que en un mundo que avanza a impulsos de estímulos contradictorios (frente a la declaración del ocaso de los deberes ${ }^{1}$

${ }^{1}$ La tensión entre el debilitamiento de los deberes y la exigencia más severa de responsabilidades puede ilustrarse con la lectura de los siguientes textos: Lipovetsky, G. «El crepúsculo del deber (la ética indolora de los nuevos tiempo democráticos)». Barcelona. Ed. Anagrama, 1994. En el otro extremo, para dar cuenta del inexorable avance de la legislación penal, Lascurain Sánchez, Juan Antonio. «¿Que les corten la cabeza?», Revista Claves de la Razón Práctica, n. ${ }^{\circ}$ 145, 2004, <http//www.cienciaspenales.net>, pp. 1-18. El lector habrá reconocido la fuente de inspiración de este título. Se encuentra en Alicia en el País de las Maravillas, de Lewis Carroll, en el que encontramos la figura de la antipática Reina de Corazones que iba fulminando, a diestro y siniestro, la pena capital: « $i$ Que le corten la cabeza!». El Derecho Penal de autor, o Derecho Penal liberal-burgués, ha dejado paso al Derecho Penal actual de las nuevas sociedades de riesgo. El paradigma no es ya la lesión de los bienes individuales, sino de los colectivos. Movimientos de masa, como las corrientes feministas, ecologistas y sindicalistas han contribuido a la tipificación de los delitos de violencia de género, medioambientales y contra la salud y la seguridad de los trabajadores, respectivamente. El Derecho Penal se encuentra en un estado de expansión neta, en el que el enemigo no es ya el ratero, sino el gestor de actividades de riesgo. Un buen exponente de 
se señala, en las antípodas de ese declinar de las obligaciones, la política de «iQue le corten la cabeza!») parece prevalecer, cuando se trata de examinar las responsabilidades profesionales, la alternativa de la mayor exigencia.

todo ello es el Proyecto de Ley Orgánica, publicado en el Boletín Oficial de las Cortes Generales de 27 de noviembre de 2009, núm. 52-1, por el que se modifica la Ley Orgánica 10/1995, de 23 de noviembre, del Código Penal, que entrará en vigor, cabe presuponer que con muy pocas variaciones sobre el texto conocido, con toda probabilidad en el presente año 2010. Su exposición de motivos explica las modificaciones que introduce en el texto vigente del Código Penal y destaca en ellas la proliferación de nuevos tipos que tienen que ver con actividades empresariales y financieras y, en general, el endurecimiento de la responsabilidad penal de los administradores formales y los administradores de hecho de las sociedades. Pero quizás la reforma estelar consista en el reconocimiento de responsabilidad criminal directa de las personas jurídicas. Esta responsabilidad no se predica respecto de todas ellas, ya que quedan exentas las Administraciones Públicas en general y, con más discutible fundamento, los partidos políticos y los sindicatos. Reza así el artículo 31 bis del proyecto: «1. En los supuestos previstos en este Código, las personas jurídicas serán penalmente responsables de los delitos cometidos, por cuenta o en provecho de las mismas, por las personas físicas que tengan en ellas un poder de dirección fundado en la atribución de su representación o en su autoridad, bien para tomar decisiones en su nombre, bien para controlar el funcionamiento de la sociedad.// En los mismos supuestos, las personas jurídicas serán también penalmente responsables de los delitos cometidos, en el ejercicio de actividades sociales y por cuenta y en provecho de las mismas, por quienes, estando sometidos a la autoridad de las personas físicas mencionadas en el párrafo anterior, han podido realizar los hechos por no haberse ejercido sobre ellos el debido control. // 2. La responsabilidad penal de las personas jurídicas no excluirá la de las personas físicas a que se refiere el apartado anterior, ni la de estas excluirá la responsabilidad penal de aquellas. Cuando como consecuencia de los mismos hechos se impusiere a ambas la pena de multa, los Jueces o Tribunales modularán las respectivas cuantías de modo que la suma resultante no sea desproporcionada en relación con la gravedad de aquellos. // 3. La concurrencia, en las personas que materialmente hayan realizado los hechos o en las que los hubiesen hecho posibles por no haber ejercido el debido control, de circunstancias eximentes de la responsabilidad penal o de circunstancias que la atenúen o agraven no excluirá ni modificará la responsabilidad penal de las personas jurídicas, sin perjuicio de lo que se dispone en el apartado siguiente. // 4. Serán circunstancias atenuantes de la responsabilidad penal de las personas jurídicas haber realizado, con posterioridad a la Comisión del Delito y a través de sus representantes legales, las siguientes actividades: // a) Haber procedido antes de conocer que el procedimiento judicial se dirige contra ellas, a confesar la infracción a las autoridades. // b) Haber colaborado en la investigación del hecho aportando pruebas, en cualquier momento del proceso, que fueran decisivas para declarar su responsabilidad. // c) Haber reparado o disminuido sus efectos en cualquier momento del procedimiento y con anterioridad a la celebración del acto del juicio oral el daño ocasionado por el delito. // d) Haber establecido, antes del comienzo del juicio oral, normas eficaces para prevenir y descubrir los delitos que en el futuro pudieran cometerse con los medios o bajo la cobertura de la persona jurídica. // 5. Las disposiciones relativas a la responsabilidad penal de las personas jurídicas se aplicarán a las asociaciones, las fundaciones y las sociedades». Como resulta del artículo 31 bis 1 que hemos transcrito, no pueden las personas jurídicas ser sujetos activos de otros delitos de los que, caso por caso y explícitamente, vaya refiriendo en cada tipo la propia legislación penal. Un examen general del Código Penal permite 
La cuestión que entonces resulta pertinente plantear es si la medida de esa responsabilidad debe ser variable y ajustarse a los vaivenes y ciclos de la

descubrir que entre dichos delitos se encuentran los relativos a la manipulación genética (art. 162 C.P.), a la propiedad intelectual e industrial, al mercado y a los consumidores (art. 288), contra la Hacienda Pública y la Seguridad Social (art. 310 bis), contra los derechos de los trabajadores (art. 318), sobre la ordenación del territorio (art. 319), contra los recursos naturales y el medio ambiente (arts. 325 y 327), contra la salud pública (arts. 366, 368, 369 y 369 bis), de tráfico de influencias (art. 430) y de corrupción en las transacciones comerciales internacionales (art. 445).

Las penas previstas para las personas jurídicas se adaptan a la especial naturaleza de estas y tienen en todo caso el carácter de graves. Dice así el artículo 33.7 del referido proyecto de Ley Orgánica de Reforma del Código Penal: «Las penas aplicables a las personas jurídicas, que tienen todas la consideración de graves, son las siguientes: // a) Multa por cuotas o proporcional. // b) Disolución de la persona jurídica. La disolución producirá la pérdida definitiva de su personalidad jurídica, así como la de su capacidad de actuar de cualquier modo en el tráfico jurídico, o llevar a cabo cualquier clase de actividad, aunque sea lícita. // c) Suspensión de sus actividades por un plazo que no podrá exceder de cinco años. // d) Clausura de sus locales y establecimientos por un plazo que no podrá exceder de cinco años. // e) Prohibición de realizar en el futuro las actividades en cuyo ejercicio se haya cometido, favorecido o encubierto el delito. Esta prohibición podrá ser temporal o definitiva. Si fuere temporal el plazo no podrá exceder de quince años. // f) Inhabilitación para obtener subvenciones y ayudas públicas, para contratar con las Administraciones Públicas y para gozar de beneficios e incentivos fiscales o de la Seguridad Social, por un plazo que no podrá exceder de quince años. // g) Intervención judicial para salvaguardar los derechos de los trabajadores o de los acreedores por el tiempo que se estime necesario, que no podrá exceder de cinco años. // La clausura temporal de los locales o establecimientos, la suspensión de las actividades sociales y la intervención judicial podrán ser acordadas también por el Juez. Instructor como medida cautelar durante la instrucción de la cau$s a »$.

Para una ampliación básica sobre la responsabilidad penal de las personas jurídicas pueden consultarse Nieto Martín, Adán, «La responsabilidad penal de las personas jurídicas: un modelo legislativo», Iustel, Madrid, 2008. Plantea aspectos tan sugerentes como los siguientes: la superación del principio societas delinquere non potest; el problema de la lesión del non bis in idem, cuando se sanciona a la vez por un mismo delito al agente persona física que lo ha cometido y a la persona jurídica; la sensible cuestión de la culpabilidad de la persona jurídica; el problema de la imputación, presentando los tres modelos: el vicarial o de transferencia de la responsabilidad (Reino Unido, Francia), el de la culpabilidad de la empresa (Austria y Suiza) y el mixto (EE. UU. e Italia). También, Wagner, Markus, «Corporate Criminal Liability. National and International Responses», Background Paper for the International Society for the Reform of Criminal Law, 13th International Conference, Commercial and Financial Fraud: A Comparative Perspective, Malta, 8-12 de julio de 1999, The International Centre for Criminal Law Reform and Criminal Justice Policy. El reconocimiento de la responsabilidad criminal de las personas jurídicas topó con una dificultad de partida, que está paradigmáticamente expresada en estas palabras del Barón Thurlow, que fue Lord Chancellor de Inglaterra en el siglo XVIII: «Did you ever expect a Corporation to have conscience, when it has no should to be damned and no body to be kicked?». La cita está tomada de Coffee, John C: «No should to damn: no body to kick and undscandalized inquiry into the problem of Corporate Punishment». Michigan Law Review, v. 79, p. 386. 
economía (para acentuarla en épocas de crisis y apaciguarla en las de prosperidad, como se adapta la velocidad de los automóviles en función de las circunstancias climatológicas) o ha de definirse sobre bases estables; $y$, en cualquiera de los dos casos, cuáles han de ser los factores o variables que han

Como es conocido, la primera vez que los Tribunales reconocieron la posibilidad de la responsabilidad penal de las personas jurídicas fue en el Reino Unido, en la sentencia Birmingham and Glowcester Railway Com. (1842) 3 Q.B. 223. Fue en el ámbito del ferrocarril en el que nació y se desarrolló la responsabilidad penal de las personas jurídicas, siempre en el mundo anglosajón. Hasta el año 1909 no se admitió en los Estados Unidos tal posibilidad. El Leading Case fue New York Central and Hudson River Railroad Company vs. U.S. 212 U.S. 481 (1909). Puede ser ilustrativo recordar los hechos enjuiciados en este caso. Los precios del transporte ferroviario entre Nueva York y Detroit estaban establecidos por tarifa administrativa. En el caso del transporte de azúcar ascendían a 23 céntimos por cada cien libras cargadas, excepto durante el mes de junio, que se rebajaban a 21 céntimos. La Ley Elkins, para evitar que las compañías ferroviarias discriminaran a los clientes y alteraran las condiciones de una competencia limpia, había definido la responsabilidad penal de las compañías y de sus agentes que manipularan las tarifas en beneficio particular de determinados clientes. En nuestro caso, la compañía W.H. Edgar and Son, intermediaria mayorista en el sector del refino del azúcar, consiguió de la compañía ferroviaria un precio de 18 céntimos por cada cien libras transportadas, esto es, una reducción de 5 céntimos sobre la tarifa ordinaria. Ello dio lugar a una serie de actuaciones que concluyeron en la apertura de un juicio criminal. En primera instancia se declaró la responsabilidad penal de la compañía ferroviaria, la cual recurrió ante el Tribunal Superior alegando la inconstitucionalidad de la sanción, basándose en que no resultaba conforme al texto fundamental la imputación de responsabilidades penales a una persona moral. El Tribunal Supremo de los Estados Unidos, en esta sentencia de referencia del año 1909, vino a reconocer la posibilidad constitucional de atribuir responsabilidad penal a la compañía mercantil. Merece la pena recoger literalmente una de las ratio decidenci del fallo: «Some of the earlier writers on common law held the law to be that a corporation could not commit a crime. It is said to have been held by Lord Chief Justice Holt that 'a corporation is not indictable, although the particular members of it are.' In Blackstone's Commentaries..., we find it stated: 'A corporation cannot commit treason, or felony, or other crime in its corporate capacity, though its members may, in their distinct individual capacities.'The modern authority, universally, so far as we know, is the other way. In considering the subject, Bishop's New Criminal Law... devotes a chapter to the capacity of corporations to commit crime, and states the law to be: 'Since a corporation acts by its officers and agents, their purposes, motives, and intent are just as much those of the corporation as are the things done. If, for example, the invisible, intangible essence or air which we term a corporation can level mountains, fill up valleys, lay down iron tracks, and run railroad cars on them, it can intend to do it, and can act therein as well viciously as virtuously.' Without citing the state cases holding the same view, we may note Telegram Newspaper Company v. Commonwealth..., in which it was held that a corporation was subject to punishment for criminal contempt; and the court, speaking by Mr. Chief Justice Field, said: 'We think that a corporation may be liable criminally for certain offenses of which a specific intent may be a necessary element. There is no more difficulty in imputing to a corporation a specific intent in criminal proceedings than in civil. A corporation cannot be arrested and imprisoned in either civil or criminal proceedings, but its property may be taken either as compensation for a private wrong or as punishment for a public wrong.' ...». 
de combinarse y ponderarse para fijar la medida adecuada de la responsabilidad.

Tal cuestión, así planteada, no está exenta de dificultades, como se puede intuir de manera inmediata, e implica no solo aspectos estrictamente legales, sino otros previos que son los que constituyen el soporte de la ley: ciencias del comportamiento, Análisis Económico del Derecho², funcionamien-

${ }^{2}$ Para una aproximación al concepto, contenidos, metodología y funciones del análisis Económico del Derecho, véase Múgica Alcorta, Ramón. «Una Introducción al Concepto y Aplicaciones del Análisis Económico del Derecho», Apuntes de Derecho Mercantil, Universidad de Deusto, 2007. El movimiento Law and Economics (L\&E) o Análisis Económico del Derecho, no ha tenido en nuestro país la fortuna que ha hecho en otros. Se merecería que le prestáramos una mayor atención. La bibliografía en este campo es oceánica. A continuación se ensaya una selección muy elemental: Alfaro Águila-Real, Jesús. «Imperialismo Económico y Dogmática Jurídica». Revista de Derecho Mercantil, número 233, 1999, páginas 925 y ss.- Becker, Gary S. (1976). «The economic approach to human behaviour». University of Chicago Press, 1976. También «Crime and Punishment». Journal of Political Economy, 6, 167 (1968).- Calabresi G. «The Cost of Accidents». University of Chicago Press, Chicago, 1971.- Coase, R. H. «La empresa, el mercado y la ley». Alianza Editorial, S. A. Madrid, 1994-Cooter, Robert y Ulen, Thomas. «Derecho y Economía». Fondo de Cultura Económica. Ciudad de México, 1998.- Hodgson, G. M. (2004). «The Evolution of Institutional Economics». Routledge.- Ibáñez Sorribes, Bartolomé. «Un ejemplo de análisis económico del Derecho: análisis de los criterios de adjudicación de un contrato de concesión». Universidad Jaime I, Castellón.- Krecké, Elisabeth. «The nihilism of the economic analysis of law». Faculty of Applied Económica, University of Aix-Marseille III, France. Levitt, Steven D. y Dubner, Stephen J. «Freakonomics (Un economista políticamente incorrecto explora el lado oculto de lo que nos afecta)». Círculo de Lectores, 2006.- Llebot Majó, J. O. «Doctrina y Teoría de la empresa en el Derecho Mercantil (una aproximación al significado de la teoría contractual de la empresa)». Revista de Derecho Mercantil, número 220, 1996. Páginas 319 y ss.- Mercuro, Nicholas and Medemea, Steven (1997). «Economics and Law: form Posner to Post-Modernism». Princeton University Press.- Nicita, Antonio y Pagano, Ugo. «Law and Economics in Retrospect». Cambridge University Press, 2005. North, Douglas. «Instituciones, cambio social y desempeño económico». Fondo de Cultura Económica, México, 1995.- Paz-Ares, Cándido. «Principio de Eficiencia y Derecho Privado». Estudios Broseta, Valencia, 1995, Volumen III, páginas 2843 y ss.- Polinsky, Mitchell. «Introducción al Análisis Económico del Derecho». Ariel Derecho. Barcelona, 1985.- Posner, Richard A. «El Análisis Económico del Derecho». Fondo de Cultura Económica, México, 1998. También «The Law and Economics Movement». Número 77 de American Economic Review, 1-13, año 1987.- Roemer, Andrés. «Introducción al Análisis Económico del Derecho». ITAM, Sociedad Mexicana de Geografía y Estadística, Fondo de Cultura Económica, México, 1994.- Rubin, Paul H. «The economicas of crime». Atlantic Economic Review, julio-agosto, vol. 28, páginas 38 y ss.- Schäfer, Hans-Bernd y Ott, Claus, «Lehrbuch der Ökonomischen Analyse des Zivilrechts». Hay traducción española de Macarena Von Carstenn-Lichterfelde: «Manual de Análisis Económico del Derecho Civil», Ed. Tecnos, Madrid, 1991.- Tommasi, M. \& Ierulli, K.. «The new economics of human behavior». Cambridge University Press, 1995.- Vázquez, Rodolfo. «Comentarios a los fundamentos filosóficos del Análisis Económico del Derecho de Robert Cooler». Gaceta de Economía, año 5, número 9.- Valle Carmona, Ariadna. «El análisis económico del delito como marco conceptual para explicar la inseguridad pública en el Distrito Federal». Gaceta de Economía, 
to de mercados, etc. Es decir, a cuestiones de política legislativa, pero también de interpretación conforme a la realidad del tiempo en que ha de ser aplicada la norma (art. 3.1 del Código Civil). El endurecimiento del régimen de la responsabilidad de los administradores puede producir dos indeseables efectos. El primero, de carácter disuasorio, consistente en desalentar a los más aptos para el ejercicio de la función, ya que, como más aptos, posiblemente sean también más conscientes y cuenten con una mayor capacidad de anticipación de las consecuencias adversas ligadas al desempeño del cargo, con lo que el sistema de selección de administradores se volvería perverso al fundarse en una especie de darwinismo a la inversa. El segundo efecto indeseable consistiría en la producción de ineficiencias, pues los administradores tratarían de acorazarse contra las responsabilidades fundando sus decisiones en un tinglado de papel (certificaciones de auditores sobre estados financieros, informes de bancos industriales sobre valor de las compañías y sobre proyectos empresariales, dictámenes jurídicos, etc.) que acaso no estén justificados conforme a la lógica del análisis coste-beneficios. No es solo una suposición la de este fenómeno (paper walls), sino que se ha verificado su existencia allí donde la exigencia de las responsabilidades se ha elevado.

La política legislativa del «ique le corten la cabeza!» puede traer otros desarreglos, a saber: un régimen sustantivo y procesal especialmente agresivo en materia de responsabilidad de los administradores «envía mensajes» inequívocos a los accionistas que especulan con la posibilidad de la presión jurídica para «guiar» al órgano de administración, haciendo de este un títere bajo la «espada de Damocles» de llevarle a los tribunales en cuanto no atienda a las demandas del grupo de accionistas activos. Este chantaje es un dato de experiencia, bien conocido por las personas que se encuentran familiarizadas con el funcionamiento de las juntas de socios de las grandes compañías. Ya Berle y Means ${ }^{3}$, en su obra clásica, y que suele citarse como antecedente del movimiento Corporate Governement, identificaban, al clasificar los casos por los que se puede ejercer el control de una sociedad, el caso marginal de las personas que, sin tener ninguna participación en el capital, lograban imponer su voluntad al órgano de administración basándose en argumentos puramente fácticos, tales como el uso de la fuerza. Esta categoría es perfectamente comprensible en el tiempo en que se publicó el libro, en pleno apogeo de las bandas de gánsteres de Chicago y Nueva York.

Año 6, número 11.- Veljanovsky, C. «Wealth Maximization, Law and Ethics: on the Limit of Economic Efficiency». International Review of Law and Economics, tomo 1, 1981, páginas 5 y siguientes.

${ }^{3}$ Berle, A. C. y Means, G. C. «The Modern Corporation \& the Private Property», New Brunswick, Transaction Publishers, 2003 (reimpresión de la obra original, que data de 1932). 
En el anterior contexto tiene sentido preguntarse si los administradores han de tener garantizado un ámbito de inmunidad; es decir, si cuando toman decisiones de gestión o de supervisión que les competen, el examen de su responsabilidad por los tribunales se halla completamente abierto, de suerte que los jueces, poniéndose -retroactivamente, pero con nuevos elementos de juicio- en el lugar de los administradores, pueden desautorizar sus decisiones y actuaciones en general; o si, por el contrario, y habiendo los administradores respetado ciertas pautas materiales y procedimentales en su iniciativa, su actuación escapa al control de los tribunales. No se trata, en consecuencia, de que se declare, después de analizada bajo la lupa judicial el detalle de esa actuación, que el administrador actuó diligente y lealmente, sino de que se limite -o autolimite- la revisión judicial, de suerte que no penetre en el examen de ese detalle, siempre que se cumplan unas condiciones previas.

Planteada así la hipótesis, resta añadir que no se debe a una ocurrencia, sino a una experiencia. En los EE. UU. existe un bagaje judicial suficientemente significativo que permite construir una doctrina al servicio de la inmunidad de los administradores. Es la Business Judgement Rule (ocasionalmente la citaremos más adelante como BJR, por su acrónimo), que no se presenta como una regla definida de una vez y para siempre, sino que es esencialmente proteica y maleable, pero, por otra parte, lo suficientemente sólida como para que no padezca la seguridad jurídica. A dicho principio, que lo aplican con solvencia los tribunales de distintos Estados y, más significativamente, la Corte de Delaware ${ }^{4}$, ha de añadirse una referencia a la doctrina recaída en el caso Caremark, que complementa la BJR y deslinda su campo de aplicación.

${ }^{4}$ Sobre la Corte de Delaware puede recomendarse la siguiente bibliografía: Parsons JR, Donald F. y Slights III, Joseph R. «The History of Delaware's Business Courts, their rise to preeminence». Business Law Today. Vol. 17, Number 4 March/ April 2008. En Delaware tienen su sede social más del $60 \%$ de las más importantes empresas del país, las top del «500 Fortune». Se trata de una Corte extraordinariamente eficiente por la claridad de sus fallos y la agilidad de sus procedimientos. Hasta la segunda década del siglo xx el Tribunal de referencia del país en el ámbito societario era el de New Jersey, pero cuando fue designado Gobernador de ese estado el luego presidente Woodrow Wilson, promovió una legislación antitrust muy severa, que obligó a huir a muchas compañías establecidas en su territorio. Emigraron en busca de nuevos aires, que fueron en los más de los casos los de Delaware. Los magistrados del tribunal de Delaware mantienen un «diálogo» (encuentros, jornadas, conferencias) abierto y constante con los abogados especialistas en Derecho de Corporaciones, con los empresarios y administradores y con los demás agentes del mundo societario. Tienen un conocimiento de la realidad más amplio que el que permite otear el periscopio de la norma. Quillen, William T. y Hanrahan, Michael. «Breve Historia del Tribunal de Justicia de Delaware. 1792-1992». Escuela de Derecho de la Universidad de Widener. 
La regla del buen juicio de los negocios y la doctrina Caremark, por efecto de la globalización jurídica ${ }^{5}$, han proyectado su eficacia también en latitudes muy alejadas del lugar en que surgieron. En esta primera parte del trabajo las analizaremos en el contexto de los principios del Gobierno Corporativo. En la segunda parte, que se anuncia para el próximo número de la revista, se examinará la posibilidad de «trasplantar» aquellos planteamientos a nuestro país, considerando si se puede trazar o seguir su rastro en la legislación, en la práctica de los tribunales y en los Códigos de Buen Gobierno hasta la fecha aprobados. Y, aunque sea adelantar mucho y disipar el suspense, no me resisto a anunciar que son tantas y tan significativas las coincidencias entre nuestro régimen y los planteamientos en el origen americano que no pueden resultar fortuitos o casuales, sino que la prueba de la genética desvela una influencia y una línea de continuidad que permiten hablar de un modelo y de una inspiración. De corroborarse esta más que hipótesis se seguirá una consecuencia inapelable: la doctrina judicial americana, un caudal de altísima calidad y cantidad, en un ámbito en el que el banco de precedentes judiciales propios tiende a ser muy limitado (sobre todo, en materia de responsabilidades por quiebra o incumplimiento del deber de lealtad de los administradores) puede ser de considerable utilidad para dar respuesta a la fenomenología que el funcionamiento de nuestras sociedades vaya deparando ${ }^{6}$.

\section{Sobre Gobierno Corporativo ${ }^{7}$}

El movimiento del Gobierno Corporativo dista mucho de ser una moda. $\mathrm{Su}$ implantación y arraigo resultan definitivos y su expansión espacial y

\footnotetext{
${ }^{5}$ La globalización jurídica en el ámbito del Derecho de Sociedades es fundamentalmente «americanización». Del mismo modo, el movimiento Corporate Governance es, en origen, una corriente norteamericana que ha acabado por exportarse con éxito a otras muchas partes del globo. En el contexto del Derecho Administrativo Económico (pero no solo en él) puede seguirse el proceso de globalización en Ballbé, Manuel. «El futuro del Derecho Administrativo en la Globalización: entre la americanización y la europeización», Revista de Administración Pública, Madrid, septiembre-diciembre 2007, núm. 174, págs. 215-276.

${ }^{6}$ Sobre la vocación expansiva del derecho americano de sociedades, Romano, R. «The genius of American Corporate Law». Washington, D.C., Ed. AEI Press, 1993. También Murthy, Narayana N.R. «Good Corporate Governance - A checklist or a mindset?». Robert P. Maxon Lectura. Georgia Washington University, 6 de febrero de 2006, para quien el derecho americano ha sido precursor o heraldo en este ámbito: "When the U.S. capital market sneezes, capital markets in ever other country match a cold».

${ }^{7} \mathrm{La}$ atención sobre asuntos que acabarían formando parte del Gobierno Corporativo viene de lejos. Podríamos remontarnos mucho más atrás, pero por su elocuencia, como manifestación de la existencia de un interés remoto, cabe citar Brandeis, Louis D. «El dinero de los demás (y de cómo lo utilizan los banqueros)». Barcelona. Ed. Ariel, 1994. Brandeis, que fue
} 
material, imparables. Lo mismo sucede con su «intensificación», esto es, con su grado de vinculación. La crisis económica actual ha puesto al Gobierno

juez del Tribunal Supremo de los Estados Unidos de América entre 1916 y 1939, escribe en la p. 81, en el Cap. IV, «Sirve a un único señor»: «La Comisión Pujo ha expuesto los hechos concernientes al Trust del Dinero tan claramente que sus conclusiones se revelan como inevitables. Su diagnóstico pone en evidencia la intensa concentración financiera y los medios mediante los cuales se lleva acabo. La concentración -el entrecruzamiento de intereses- aparece como el mal que impregna todo el sistema actual. Con el propósito de liberar a la industria, la Comisión recomienda la implantación de 21 medidas legislativas específicas. La mayor parte de las medidas propuestas están sabiamente configuradas para hacer frente a alguno de los abusos puestos en evidencia por la investigación, y si todas ellas se adoptasen por el legislador, aliviarían sin duda el sufrimiento que hoy se padece y contribuirían a atajar la enfermedad. Pero la mayor parte de las soluciones propuestas tienen un alcance tópico; y la sanción no es posible sin un tratamiento que ataque la raíz. De hecho, lo que se necesita es cirugía mayor: la Comisión no se ha atrevido a formular tan severa recomendación. No obstante, el remedio necesario es simple: "Solo se puede servir a un señor"».

La bibliografía sobre la rúbrica Corporate Governance es prácticamente inabarcable. Solo una muestra en lo que sigue: Augustine, M. Sean y Cooper, Cecily D. «Getting the Most from Strategic Partnering: A Tale of Two Alliances». Organizational Dynamics. Vol. 38, Issue 1, enero-marzo 2009, pp. 37-51.- Asare, Stephen Kwaku, Cunningham, Lawrenc e A. y Wright, Arnold. «The Sarbanes Oxley Act: Legal Implications and Research Opportunities». Research in Accounting Regulation. Vol. 19, 2007, pp. 81-105.- Borio, Claudio y Tsatsaronis, Kostas. «Accounting and prudential regulation: from unconfortable bedfellows to perfect partners?». Journal of Financial stability. Vol.1, Issue 1, septiembre 2004, pp. 111-135.- Bainbridge, Stephen M. «The new Corporate Governance in theory and practice». Oxford University Press Us.2008. ISBN 0195337506, 9780195337501.- Idem. «Why a Board? Group Decisionmaking in Corporate Governance». Vanderbilt Law Review. Vol. 25, N. ${ }^{\circ}$ 1, enero 2002.- Idem. «Director Primacy: The means and the ends of Corporate Governance». Northwestern University Law Review. Vol. 97, N. ${ }^{\circ}$ 2, 2003.- Baums, Theodor y Scott, Kenneth E. «Taking Shareholder Protection Seriously? Corporate Governance in the United status and Germany». The American Journal of Comparative Law. Vol. 53, N. ${ }^{\circ}$ 1, Invierno 2005.- Bozec, Richard y Dia, Mohamed. «Board structure and firm technical efficiency. Evidence from Canadian state-owned enterprises». European Journal of Operational research. Vol. 177, Issue 3,16, marzo 2007, pp. 1734-1750.- Clarke, Donald C. «The Independent Director in Chinese Corporate Governance». Delaware journal of Corporate Law. Vol. 31, N. ${ }^{\circ}$ 1, pp.125-228, 2006. Clarke, Donald C. «The Independent Director in Chinese Corporate Governance». Delaware journal of Corporate Law. Vol. 31, N. ${ }^{\circ}$, pp. 125-228, 2006.- Clark, Gordon L. y Wojcik, Darinsz. «The geography of finance: Corporate Governance in The Global Marketplace». Oxford University Press. Oxford, 2007.Dooley, Michael P., Veasey, E. Norman. «The Role of Corporate litigation in the TwentyFirst Century». Delaware journal of corporate Law. Vol. 25, N. ${ }^{\circ}$ 1, pp.131-160, 2000.- Everett, Jeff, Neu, Dean y Rahaman, Abu Shiraz. «Accounting and the global fight against corruption». Accounting, Organizations and society. Vol. 31, Issue 6, agosto 2007, pp. 513542.- Friedman, Milton. «The Social Responsability of Business Is to increase Its profits». The N.Y Times. 13 de septiembre de 1970, pp. 1232 y ss.- Fulmer, Robert M. «The Challenge of Ethical Leadership». Organizational Dynamics, Vol 33, Issue 3, agosto 2004, pp. 307317.- Guerra, Jorge E. «The Sarbanes-Oxley Act and Evolution of Corporate Governance». The CPA Journal, marzo de 2004.- Hatch, Mary Jo y Schultz Majken. «Of Bricks and 
Corporativo en el centro de la escena del Derecho y de la práctica de las compañías. El debate postcrisis en este campo encuentra un exponente ejemplar en el Informe Walter ${ }^{8}$, publicado el 26 de noviembre de 2009 y que, si bien incide sobre las rúbricas de siempre (las funciones y estructura del consejo de administración; su tamaño, composición y cualificación de sus miembros; el funcionamiento del consejo y evaluación de su rendimiento; el papel de los inversores institucionales, la gestión del riesgo; y la remuneración de los consejeros), aporta nuevas reflexiones y consejos de alto interés.

Brands: From Corporate to Enterprise Branding». Organizacional Dynamics. Vol. 38, Issue 2, abril-junio 2009, pp. 117-130.- Herrigel, Gary. «A New Wave in the History of Corporate Governance». Oxford University Press on behalf of the Business History Conference. Publicado online el 27 de agosto de 2007.- Hutchinson, Harry G. «Director Primacy and Corporate Governance: Shareholder Voting Rights Captured by the Accountability/Authority Paradigm». Loyola University Chicago law Journal. Vol. 36, pp. 1111-1203, 2005.Kammerer, Matthias. «Creative Accounting, the Enron Case and its Impact in Corporate Governance». Akademische Schriftenreihe. Grin Verlag, 2009.- Kerr Jeffrey L. y Werther Jr., William B. «The Next Frontier in Corporate Governance: Engaging the Borrad in Strategy». Organizacional Dynamics. Vol. 37, Issue 2, abril-junio 2008, pp. 112-124.- Kiessling, Timothy S., Marino, Louis D. y Richey, R. Glenn. «Global Marketing teams: A Strategic Option for Multinationals. Organizational Dynamics. Vol. 35, Issue 3, 2006, pp. 237-250.Macavoy, Paul W. y Millstein, Ira M. «The recurrent crisis in Corporate Governance». New York: Palgrave MacMillan, 2003.- Moehrle, Stephen R. y Reynolds-Moehrle, Jennifer A. «Developments in Accounting Regulation: A Synthesis and Annoted Bibliography of Evidence and Commentary in the Academic Literature (2003-2004)». Research in Accounting Regulation. Vol. 18, 2005, pp. 233-277. Napier, Christopher J. «Accounts of change: 30 years of historical accounting research». Accounting Organizations and Society. Vol. 31, Issues 4-5, julio-agosto 2006, pp. 445-507.- Okereke, Chukwumerije. «Global environmental sustainability: Intragenerational equity and conceptions of justice in multilateral environmental regimes». Geoforum. Vol. 37, Issue 5, septiembre 2006, pp. 725-738.- Prokopiadou, Georgia, Papatheodorou, Christos y Moschopoulos, Dionysis. «Integrating Knowledge management tools for government information». Government Information Quarterly. Vol. 21, Issue 2, 2204, pp. 170-198.- San Sebastián Flechoso, F. «El gobierno de las sociedades cotizadas y su control». Madrid. Ed. Centro de Documentación Bancaria y Bursátil, 1996. Idem. «Reflexiones sobre Gobierno Corporativo comparado». Revista de Derecho Bancario y Bursátil, 1988.- Idem. «Algunas reflexiones sobre Gobierno Corporativo». Boletín de Estudios Económicos de la Universidad de Deusto, 2008.- Sleeman, Bill. «Recent literature on government information». Journal of Government Information. Vol. 30, Issue 1, 2004 , pp, 20-41.- Waddock, Sandra. «Pragmatic Visionarios: Difference Makers as Social Entrepreneurs». Organizacional Dynamics. Vol. 38, Issue 4, octubre-diciembre 2009, pp. 281289. Wade, James B., Porac, Joseph F., Pollock, Timothy G. y Graffin, Scout D. «Star CEOs: Benedict or burden?». Organizational Dynamics. Vol. 37, Issue 2, abril-junio 2008, pp. 203 210. Williams, Paul. F, Jenkins, J. Gregory y Ingraham Laura. «The winnowing Hawai of behavioural accounting research in the US: The process for anointing academia elites». Accounting, Organizations and Society. Vol. 31, Issue 8, noviembre 2006, pp. 783-818.

8 «A review of corporate governance in UK banks and other financial industry entities. Final recommendations». 
El Gobierno británico ha anunciado su intención de introducir un régimen fiscal gravoso para los bonus que las entidades de crédito abonen a sus ejecutivos $^{9}$. Entre nosotros, el anteproyecto de Ley de Economía Sostenible contempla, en su caleidoscópica relación de medidas, la de reforma de la Ley del Mercado de Valores para incorporar la obligación de las sociedades cotizadas de poner a disposición de los accionistas un informe sobre remuneraciones de los administradores y la necesidad de votarlo en la Junta General, así como el detalle de las retribuciones «individuales» de cada uno de los consejeros.

En fin, la referida atención creciente por las cuestiones de Gobierno Corporativo no es sino una manifestación particular de un fenómeno más comprensivo, que es el de la importancia que adquieren los asuntos de la «Gobernanza», la cual, trascendiendo su marco conceptual originario, alcanza también al sector privado de los negocios ${ }^{10}$.

Hay del Gobierno Corporativo dos concepciones metodológicas fundamentales. La primera consiste en concebirlo como un cuestionario o lista de condiciones normalizadas. La segunda presenta una versión más flexible, y también más etérea, del Gobierno Corporativo, considerándolo una mentalidad o una especie de cultura empresarial. Posiblemente ambas visiones sean complementarias. En cualquier caso coinciden en algo fundamental: las dos tienen aspiraciones de globalización; es decir, una y otra subrayan la necesidad de que las condiciones del buen Gobierno Corporativo sean universales, pues el modelo de mosaico o astillamiento geográfico obligaría a realizar ajustes en la concepción de los agentes cada vez que se produjera un traslado o cambio de país. En un mercado global la exigencia de Gobierno Corporativo ha de ser también global o uniforme, la misma para cualquier lugar ${ }^{11}$.

\footnotetext{
${ }^{9}$ Se puede leer en The Wall Street Journal del 10 de diciembre de 2009 la siguiente crónica: «Authorities on both sides of the Atlantic are moving to enact tough curbs on pay, in an indication that governments are taking increasingly aggressive steps to rein in compensation after the financial crisis. In the U.S., the Treasury Department's pay czar, Kenneth Feinberg, is poised to enact tougher-than-expected rules for employees at companies that received large amounts of government assistance. The U.K. on Wednesday slapped banks with a $50 \%$ tax on portions of bonuses they pay to individuals, in perhaps the most aggressive move yet by a government». (Deborah Solomon, Sara Schaefer Muñoz y Alistair Macdonald).

${ }^{10}$ Véase Cerrillo i Martínez, A. (Coordinación). La Gobernanza hoy: 10 textos de referencia. Ed. Instituto Nacional de Administración Pública, Madrid, 2005. Especialmente la «Introducción», del propio Cerrillo, pp. 11-31 y Peters, G. B. y Pierre, J. «¿Por qué ahora el interés por la Gobernanza?».

${ }^{11}$ Sobre las dos concepciones del Gobierno Corporativo es muy ilustrativa la Conferencia de Narayana N. R. Murthy, op. cit. Es fácilmente localizable en Internet. Para el autor el sistema de una regulación checklist no puede asegurar el comportamiento ético de las compañías y propone un nuevo balance o equilibrio de poder dentro de ellas, el incremento de la obligación de dar cuentas los administradores a los accionistas, la creación e impulso de una mentalidad de decencia y honestidad, un liderazgo de los administradores, que
} 
En el proceso de normalización de los factores que dan la medida de un buen Gobierno Corporativo de la compañía se han llegado a elegir tres como principales: la transparencia, la composición del Consejo de Administración y el estilo de trabajo del Consejo. A su vez, cada uno de estos factores se descompone en diversos subfactores o variables. Así, la transparencia abarca la apertura de información sobre los administradores (si son ejecutivos, accionariales o independientes; identidades; género; conexiones empresariales; experiencia y formación, etc.), el sistema de su retribución e incentivos, y la existencia de Comités Delegados de Consejo (por ejemplo, de retribuciones, de auditoría, de responsabilidades, de cumplimiento normativo, incluso del Gobierno Corporativo, etc.). El segundo factor, relativo a la composición del Consejo, incide en la existencia de Consejeros o Administradores independientes, su diversidad (buscando la internacionalización, la complementariedad en la experiencia que aporta cada uno y también la diversidad de sexo) e igualmente en la composición de los Comités Delegados (procurando, como opción preferible, que el Presidente de los Comités sea independiente y tratando de conseguir una distribución personal que garantice la calidad del órgano). Y en cuanto al estilo de actuación o trabajo del Consejo, se hace hincapié en la disponibilidad del órgano de Administración (frecuencia de las sesiones, asistencia a estas, dedicación de los Administradores), en la existencia de sistemas de evaluación del Consejo (liderazgo, procesos, etc.) y en el análisis de los factores de inercia (duración en el cargo, permanencia en el Consejo, rotación en él, etc.).

Heidrick \& Struggles, en su Informe para $2009^{12}$ presenta un ranking sobre calidad del Gobierno Corporativo de los trece países objeto de su estudio, que reproducimos a continuación, porque da una idea cabal de lo que, en términos generales, ha de recorrerse todavía.

abandonando su estilo de casi-Dioses, les lleve a predicar con el ejemplo («Walk the talk») y, finalmente, propugna la simplificación de las reglas: «CEOs must follow simple business rules. Great corporate leaders are expert simplifiers. They operate on simple business rules. Such rules are easy to understand, easy to follow and easy to communicate. After all, you cannot cheat people with simple rules. Without exception, every corporation that violated basic governance principles did so by creating a web of complex and confusing rules.».

${ }^{12}$ Heidrick \& Struggles. Corporate Governance Report 2009. «Boards in turbulent times». Austria, Belgium, Denmark, Finland, France, Germany, Italy, Netherlands, Portugal, Spain, Sweden, Switzerlnd, United Kigdom. Se puede localizar en Internet. 


\section{$\mathrm{C} \mathrm{GO} 9^{2009}$ Corporate governance ratings \\ (conformity with stated governance criteria)}

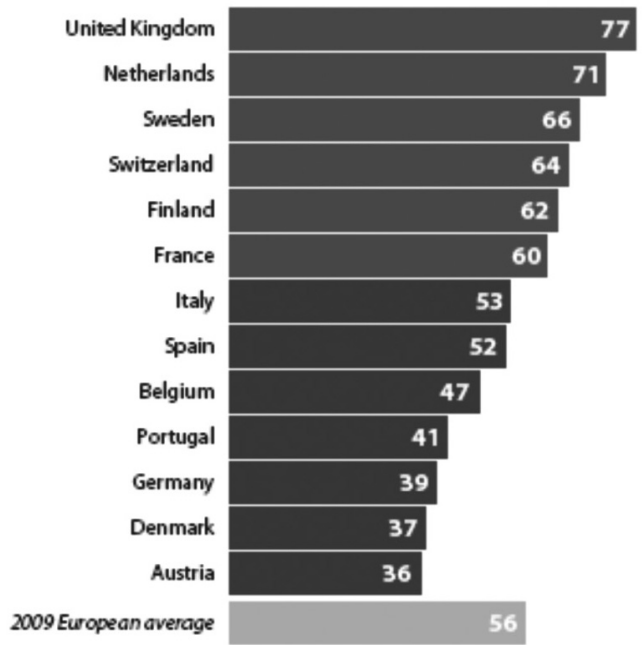

Del mismo informe interesa en este momento reflejar el cuadro de la duración media en el cargo de los administradores.

\section{figure 10}

C 709 Average length of tenure of board directors

(length of appointment)

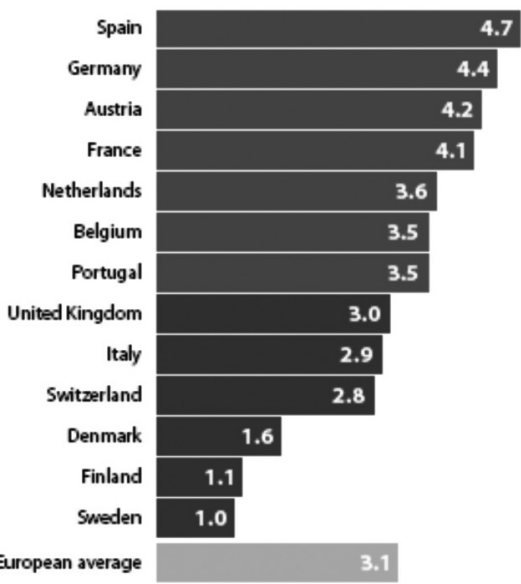


Por último, se refleja en el siguiente cuadro la proporción de mujeres miembros del Consejo de Administración, con indicación de la tendencia desde el año 2001 hasta el presente.

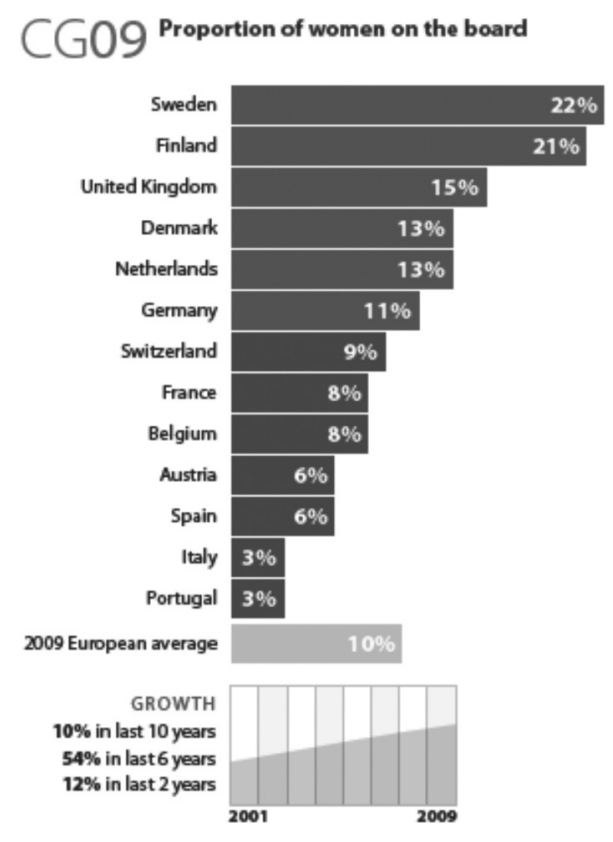

\section{La expansión del Buen Gobierno Corporativo}

El Gobierno Corporativo es una creación norteamericana. Su historia formal se remonta a un par de décadas atrás, sin perjuicio de que con anterioridad, sin utilizar la etiqueta «Gobierno Corporativo», ya fueran analizados con detenimiento asuntos que constituyen su objeto típico de atención (remuneración de los administradores, equilibrio de poderes entre socios y administradores, delegación de votos, comités delegados del consejo, concentración o no en una misma persona del doble rol de primer ejecutivo -CEO- y de presidente del Consejo de Administración -Chairman of the board-, etc.).

Es sabido, por otra parte, que el Gobierno Corporativo aspira a alinear los intereses de los accionistas con los incentivos y los intereses de los administradores, lo que, en el ámbito de la responsabilidad de estos, en el que focalizamos la atención de nuestro estudio, significa que han de cumplir con los deberes fiduciarios de diligencia, lealtad y buena fe, actuando siempre en 
servicio del interés social, entendido este como el interés de los socios. Explicado sumariamente, este interés consistiría en maximizar el valor de las inversiones de los accionistas, con la importante precisión de que esa maximización habría de obtenerse de manera sostenible ${ }^{13}$, es decir, en el medio y largo plazo, y no rabiosamente en el corto. No puede confundirse el concepto de Gobierno Corporativo con el de Responsabilidad Civil Corporativa. Este segundo objetivo es multidimensional, y apela a una relación de servicio y cumplimiento de la compañía con una pluralidad de agentes, colectivos y bienes con los que se relaciona o entra en contacto: proveedores, clientes, trabajadores, gobiernos locales, medio ambiente, etc. Es decir, apela a la forma de integrarse la compañía en el conjunto de la sociedad.

El movimiento Corporate Governance, avanzando en mancha de aceite, ha experimentado una triple expansión:

a) la de índole geográfica, al traspasar las fronteras de su país de origen y alcanzar a las economías con un cierto tejido empresarial de base corporativa. No ha detenido su progreso en la Europa occidental, sino que llega a las economías emergentes y, así, por ejemplo, en China e India empiezan a proliferar las obras científicas sobre el tema y la atención de los empresarios hacia el Gobierno Corporativo es bien palpable;

b) la que afecta al campo normativo de juego, con lo que quiere expresarse que los principios de Buen Gobierno Corporativo, extraídos del solar de la ética, se transvasan al terreno de lo jurídico. Se puede rastrear este paso con seguridad en alguna de nuestras leyes ${ }^{14}$. Bien puede decirse que aquí, como en otros muchos casos, las recomendaciones que contienen los Códigos de Buen Gobierno en una buena medida serán las leyes del futuro. Por lo tanto, se encuentran en un estado intermedio o de tránsito. De hecho, la condición comply or explain ya lleva al ánimo la idea de que, aunque no sean normas jurídicamente vinculantes, tienen más fuerza jurídica que las reglas morales; $y$

c) la ampliación que hace referencia a los sujetos o entidades destinatarios de los principios, pues si en la fase actual proyectan su eficacia sobre las sociedades cotizadas en los mercados de valores, en lo sucesivo podrían estirar su radio para aplicarse también a las sociedades no cotizadas.

Este pronóstico obliga a intentar alguna explicación adicional que nos ayude a enmarcar el ámbito de influencia del Gobierno Corporativo. Tal vez la forma más sencilla de adquirir una visión comprensiva y sistémica consista en representarse la compañía mercantil como el centro planetario en tor-

${ }^{13}$ Narayana R. N. Murthy. Op. cit.: «Longevity is the best index of success of a corporation».

${ }^{14}$ Así, en la Ley26/2003, de 17 de julio, por la que se modifican la LSA y la LMV con el fin de reforzar la transparencia de las sociedades anónimas cotizadas (BOE núm. 171, de 18 de julio). 
no al cual orbitan una serie de exigencias de conducta, hasta tres. La primera viene representada por la demanda del mercado (de los mercados de capitales, de los mercados de valores). La legislación tradicionalmente no garantizaba la «calidad» del producto de inversión que se podía adquirir en la Bolsa. Es una constante histórica del régimen legal regulador del procedimiento de admisión a cotización de las acciones que este se centrara en un examen de carácter fundamentalmente formal y externo de la sociedad que hacía la solicitud. Al inversor correspondía la decisión de invertir si quería, y de hacerlo entre las diferentes acciones o sociedades cotizadas. Eran suyos la decisión y el riesgo anejo, y en gran medida siguen siéndolo. Puede optar por dirigir sus ahorros a una blue chip o a un «chicharro», y la Comisión Nacional del Mercado de Valores, entre nosotros, no responderá si la elección resulta poco afortunada. Más recientemente, sin embargo, los inversores han demandado un buen comportamiento de las compañías cotizadas, y el legislador ha considerado de interés general responder a esa pretensión a través de un instrumento que persigue tendencialmente implantar una cultura ética de diligencia, honestidad y racionalidad, en la organización y funcionamiento de las compañías cotizadas. Así nacen los Códigos de Buen Gobierno ${ }^{15}$.

${ }^{15}$ La enumeración de los Códigos de Buen Gobierno se haría interminable. En los últimos años han proliferado de tal modo que su seguimiento -e incluso su mera cita- constituiría una labor extenuante; y no digamos ya su exposición detallada: el lector perecería en el intento de abarcarla. Sí cabe decir, a los meros efectos de facilitar la construcción de un mapa mental, que todo ese material puede sistematizarse del siguiente modo: a) Códigos de Buen Gobierno de origen privado, las más de las veces procedentes de asociaciones empresariales u otras organizaciones semejantes. Tal sería el caso, por ejemplo, de los «Principios de Buen Gobierno Corporativo» del ICA, Instituto de Consejeros-Administradores, que contiene una relación de buenas prácticas para los consejeros y el consejo (Madrid, primera edición de 2004). Otra referencia ilustre la constituye el «Code de Gouvernement d'Entreprise des Sociétés Cotées», de la AFEP, Association Française des Entreprises Privées, diciembre de 2008; b) Códigos procedentes de organismos internacionales y cuya utilidad radica en su propósito normalizador, que se aviene muy bien con las demandas de la globalización. Sirvan de muestra, primero, la inevitable cita del activismo que opera en el seno de la Unión Europea, que arranca con las dos entregas del Informe Winter -Informe del Grupo «de alto nivel» de expertos en Derecho de Sociedades: «Un marco normativo moderno para el Derecho de Sociedades en Europa»-, seguido de incontables medidas implementadotas; y, segundo, el documento «Principles of Corporate Governance», 2004, de la Organización para la Cooperación y el desarrollo Económicos, OCDE.; c) Códigos oficiales de escala nacional, cuyo procedimiento de elaboración suele ajustarse a un esquema muy semejante: encargo del Gobierno a un grupo de expertos, que presenta un informe, el cual acaba siendo encapsulado en una norma en cuya aprobación se produce una intervención destacada del organismo rector correspondiente de los mercados de valores. Es el caso de referencia, del Reino Unido, que se remonta al año 1992, con el famoso y tantas veces referido Informe Cadbury, así llamado por ser Sir Adrian Cadbury el presidente del Comité que presentó «The Code of Best Practice». En España, las Comisiones Olivencia, Aldama y Conthe también rindieron sus respectivos informes. Fruto de la última es el vigente Código Unificado de Gobierno Corporativo, aprobado por el Consejo de la Comisión Nacional del Mercado 


\begin{abstract}
¿Son garantía estos códigos de la calidad del producto de inversión? No necesariamente. Incluso algún cínico o descreído podría llegar a alegar que, cuanto más inmoral resulte la gestión de una compañía (por ejemplo, si pagara comisiones para inclinar a su favor la adjudicación de contratos públicos o recurriera al espionaje ${ }^{16}$ ), más exitosa resultará en términos económicos, al menos en el corto plazo.
\end{abstract}

de Valores el 22 de mayo de 2006, con el carácter de «documento único con las recomendaciones de gobierno corporativo, a efectos de los dispuesto en el apartado primero f) de la Orden ECO/3722, de 26 de diciembre». Constituye una empresa ambiciosa y extensa, pues reúne hasta 58 recomendaciones. No obstante, esta realización, que obedecía a un encargo de refundición de textos anteriores, posiblemente incurra en ultra vires: desborda los términos de la encomienda.

Aún interesa añadir dos precisiones: I) que los principios de Buen Gobierno Corporativo pueden ampliarse o complementarse mediante reglas individuales dictadas para cada compañía (contenidas en sus estatutos sociales o, cuando resultan preceptivos o existen, en los reglamentos de la junta general y del consejo y, aún todavía, en eventuales códigos de principios éticos); II) que con el tiempo, algunos de los principios o recomendaciones de Buen Gobierno terminan transmutándose en normas jurídicas de derecho imperativo. Dos ejemplos de ello lo constituyen, para EE. UU. la Ley Sarbanes-Oxley de 23 de enero 2002, cuyas secciones 101 a 109 constituyen y regulan, para asegurar la eficacia de las medidas que contiene, un organismo público: «Public Company accounting Oversight Board» (Sec. 101 [a]. Establishment of Board.- There is established the Public Company Accounting Oversight Board, to oversee the audit of public companies that are subject to the securities laws, and related matters, in order to protect the interests of investors and further the public interest in the preparation of informative, accurate and independent audit reports for companies the securities of which are sold to, and held by and for, public investors. The Board shall be a body corporate, operate as a nonprofit corporation, and have succession until dissolved by an Act of Congress). El segundo caso es el español, en el que cabe recordar cómo la Ley 26/2003, de 17 de julio por el que se modifican la LSA y la Ley del Mercado de Valores, ley llamada de transparencia de sociedades anónimas cotizadas, opera un transvase parcial de los principios de Buen Gobierno a normas puras y duras.

${ }^{16} \mathrm{El}$ caso del espionaje empresarial no es tan infrecuente como pueda imaginarse. Nos referimos ahora, no al espionaje industrial, como actividad contraria a la competencia o a la propiedad industrial, sino al espionaje de los propios socios de la compañía. El pasado verano saltó a la prensa un caso muy ilustrativo, el de Deutsche Bank. El diario El País del 27 de julio de 2009 daba la noticia bajo el titular «El Deutsche Bank protagoniza otro escándalo en Alemania». Se trataba de una historia de espías, seducción e intriga. El despacho de abogados BuB, Gauweiler and Partner concedió una entrevista de trabajo a la Srta. Traudel Schmitt, de la que más tarde se sospechó podía ser espía del Deutsche Bank. El despacho en cuestión prestaba asistencia legal al magnate de los medios Leo Kirch, quien mantenía un pleito multimillonario contra el Banco. La razón última de su demanda consistía en que un expresidente ejecutivo de Deutsche Bank provocó en el año 2002 la bancarrota del imperio mediático de Kirch al manifestar públicamente que era «cuestionable» que Kirch pudiera refinanciar los miles de millones de euros de deuda que soportaba su empresa.

Por otra parte el accionista rebelde de Deutsche Bank, Michael Bohndorf, abogado jubilado de Hamburgo, cuestionaba insistentemente la línea de acción del Presidente Clemens Börsig, habiéndole hostigado con cierta firmeza en la Junta de Socios. El Presidente Börsig pidió al Director de Relaciones con los inversionistas de Deutsche Bank, Schmitt, que inves- 
La pregunta que cabe entonces hacer es si los principios de Buen Gobierno añaden valor -económico- a la empresa. En realidad, la pregunta se podría formular con más precisión bifurcándola: (a) ¿es el Buen Gobierno un activo intangible que produce una mayor estima o aprecio de parte de los inversores, de suerte que estos estarían dispuestos a pagar más por la acción de una sociedad que respeta los principios de Gobierno Corporativo?; y (b) ¿son los principios de Buen Gobierno fuentes de generación de riqueza o beneficio adicional para la compañía, pues la mejor administración se traslada de manera mensurable y objetiva a la cuenta de resultados y al valor de las inversiones? Son dos aspectos diferentes del mismo tronco. El primero hace referencia a la apreciación subjetiva, que se traduce en un dato mensurable: la cotización bursátil. El segundo guarda relación con el valor fundamental de la empresa. No hay evidencia empírica que permita asegurar respuestas concluyentes, pero la ciencia económica sí intuye con vehemencia la existencia de un nexo o relación de causalidad que autoriza a concluir

tigara a Bohndorf. Estaba muy interesado en conocer si el abogado trabajaba en conexión con Kirch, el ex magnate mediático.

Smitt contactó con el Jefe de Seguridad de Alemania del DB, y luego ambos buscaron la ayuda de Bernd Bühner, un ex oficial de seguridad del ejército alemán que contaba con una agencia de detectives privados. El encargo que se hizo a este consistió en averiguar si Bohndorf y Kirch trabajaban juntos. A tal fin le entregaron una lista de veinte objetivos a investigar. Bühner organizó un plan de acción con dos equipos: el equipo Deutschland y el equipo Balearia. En 2006 este segundo equipo fue destinado a Ibiza. Unas pocas semanas después, declaró Bohndorf, se encontraba él sentado en la terraza de un café cuando una joven brasileña ocupó la mesa de al lado. «Esta es una isla tan romántica...», dijo sonriéndole. Se presentó como Adriane. Vivieron un romance de una semana, según contó Bohndorf. Luego ella desapareció sin despedirse ni dejar rastro. Bahndorf manifestó que creía que el DB montó esta operación para obtener información sobre él, pues la mujer no dejaba de hacerle preguntas. El equipo despachado a Ibiza registró sus dos casas, una en la isla y otra en Múnich.

La joven abogada, Traudel Schmitt (ahora utiliza su nombre de casada, Traudel Blecher), que había acudido a la entrevista de trabajo en respuesta a un anuncio de la prensa, solo participó en una reunión en que se planteó cuál debía ser la estrategia en el pleito de DB con Kirch. DB decidió poner fin a todas sus iniciativas de investigación, pero el abogado señor Gauweiler, miembro del Parlamento alemán, declaró que había que seguir haciendo indagaciones porque había indicios de que gerentes del DB estuvieron implicados durante semanas en una actividad delictiva organizada. En cualquier caso, estos hechos llegaron al fiscal de Frankfurt, que inició las consiguientes actuaciones. DB, al objeto de depurar los hechos, encargó una investigación a la firma de abogados neoyorkina Cleary Gottlieb Steen \& and Hamilton LLP, que en julio de 2009 presentó un informe de 180 páginas en el que se identificaban cuatro casos de investigación o de espionaje, pero las responsabilidades se detenían en cargos directivos medios. En cualquier caso, todos estos sucesos debilitaron las expectativas de Börsig, que aspiraba a colocarse a sí mismo como sucesor de Akermann en la presidencia del DB. El intento de Börsig de alzarse a la presidencia, que algún diario alemán calificó de «intentona golpista» podría haber contribuido a la filtración del escándalo del espionaje. 
que el Buen Gobierno Corporativo es fuente de ventajas. Sin embargo, en punto a la estimación de la compañía desde el punto de vista del inversor, parece que este preferiría, ceteris paribus, invertir en acciones de compañías que observen los Códigos de Gobierno Corporativo, pero si la opción económica (posibilidad de ganancia) es más favorable para una inversión bursátil competidora que no fuera tan escrupulosa, optaría por esta última, lo que significa que en la opción entre ética y economía sería la segunda la fuerza dominante. Podría, no obstante, tener gran interés construir la curva de la preferencia economía-ética del inversor sobre un eje de abscisas y ordenadas según una muestra significativa de datos.

Habíamos reseñado más arriba que alrededor del «núcleo compañía mercantil» giran una serie de demandas y condicionamientos. El económico (o del mercado de capitales) ha sido examinado y es hora de añadir los otros dos: el moral y el jurídico. A estos dos últimos no es necesario hacer ahora una referencia detenida, pues ya han quedado aludidos, de manera suficiente a nuestros efectos, con anterioridad. Pero sí interesa decir que todos ellos, los tres, no son elementos fijos, sino dinámicos, y giran alrededor de la empresa, e interactúan unos con otros entre sí y también con la realidad central o planetaria de la compañía. Retener esta imagen, esta estampa «astronómica», puede servir como mapa general para entender mejor la acción que despliega el Buen Gobierno Corporativo.

\section{Crisis económica y gestión de riesgos}

La presente crisis ha producido enorme desconcierto y, sin la suficiente reflexión, como quien se agarra a un clavo ardiendo, se hacen propuestas precipitadas para enderezar el rumbo y evitar repetir el suceso ${ }^{17 / 18}$. Los espe-

${ }^{17}$ Para una aproximación, aunque sumaria vívida, a la crisis finaciero-económica de los dos últimos años y una exposición elemental de sus consecuencias pueden ser de utilidad las siguientes fuentes:

Carr, Edward. «Greed -and fear: A special report on the future of finance», The Economist Magazine, 24 de enero de 2009.- Kiviat, Barbara. «Can Wall Street find a safer way to package assets?» Time Magazine, enero de 2009.- Mc Donald, Lawrence y Robinson, G. Patrick. «A Colossal Failure of Common Sense: The Inside Story of the Collapse of Lehman Brothers». Deckle Edge, julio de 2009. -Palmer, Andrew. «Rebuilding the Banks: A special report on international banking», The Economist Magazine, 16 de mayo de 2009.Saporito, Bill (30 de marzo de 2009), «How AIG became too big to fail», Time Magazine, págs. 14-22.- Serwer, Andy y Sloan, Allan. «The price of greed: how Wall Street took a mighty fall- and brought markets around the world down with it». Time Magazine, 29 de septiembre de 2009, págs. 18-23.- Sorkin, Andrew R. «Too Big to Fail: The Inside Story of How Wall Street and Washington Fought to Save the Financial Systems-and themselves», Viking, 2009.- Taleb, Nassim N. «The six mistakes executives make in risk management», Harvard Business Review - Spotlight on risk, octubre 2009.- The Economist Magazine. «Wall Street's new shape: Rearranging the towers of gold», 10 septiembre 2009. 
cialistas en Gobierno Corporativo son unánimes al señalar que ha fallado la gestión de los riesgos empresariales. En muchos casos, el riesgo ni siquiera se gestionaba, no se incorporaba como una variable más a considerar en el diseño y ejecución de la estrategia empresarial. Aún más importante, encuestas realizadas entre miembros de los Consejos de Administración revelan con claridad que los administradores permanecían en un gran número de casos ignorantes de los riesgos a que se enfrentaban sus respectivas compañías ${ }^{19}$.

${ }^{18}$ Sobre la ambivalencia de los «Resultados empresariales y económicos» de la observancia de los principios de Buen Gobierno Corporativo que arroja las investigaciones empíricas, pueden consultarse: Shivdasani, A. y Yermack, D. «CEO Involvement in the Selection of New Board Members: An Empirical Análisis», Journal of Finance, 54 (1999), pp. 1829-1854; Agrawal A. y Knoeber Ch. R., «Firm Performance and Mechanisms to Control Agency Problems between Managers and Shareholders», Journal of Financial and Quantitative Análisis, 31 (1966), pp. 377-378; Rediker, K. J. y Seth A., «Boards of Directors and Substitution Effects of Alternative Governance Mechanisms», Strategic Management Journal, 16 (1995), pp. 97-98; Fama, E., «Agency Problems and the Theory of the Firm», Journal of Political Economics, 88 (1980), pp. 288-307; Perry T., «Incentive Compensation for outside Directors and Ceo Turnover», working papers disponibles en <http://papers. ssrn.com> (julio 2000); y Romano R., «Less is More: Making Institucional Investor Activism a Valuable Mechanism of Corporate Governance», working paper disponible en el sitio $<$ http://papaers.ssrn.com> (2000). En este ultimo rabajo se cita una amplia relación de estudios de alto interés.

Quizás una síntesis definitiva acerca de la falta de resultados concluyentes en este asunto sea la del premio Nobel Robert M. Solow: «in economics, model-builders busywork is to refine their ideas to ask questions to which the available data cannot give the answer.. We have the overeducated in pursuit of the unknowable». En «How Did Economics Get That Way and What Way Did it Get», Journal of American Academy of Arts and Sciences (Winter 1997), 57, Solow también apuntó: «there is a tendency to undervalue keen observation and shrewd generalization... There is a lot to be said in favour of staring at the piece of reality you are studying and asking, just what is going on here?». Se preguntaba Millstein Ira M., "The State of Corporate Governance» en su discurso ante la National Association of Corporate Directors, 1 noviembre de 1993, recogido en Monks, R. A.G. y Minow, N., «Corporate Governance» (1995), 445, p. 451: «But does the absence of conclusive empirical proof... mean we should ignore the obvious linkage». Y se respondía así: «To me is intuitively correct that to maximize the corporation's wealth-producing capacity we must ensure that the accountability mechanism provided in the legal structure of the governance system works... Think about it: no one questions that de CEO's performance matters a great deal to corporate performance. And the board is charged with hiring the best CEO it can find, helping the CEO set goals and priorities for the long-term viability of the corporation, monitoring his or her accomplishments against those goals and, if necessary, replacing him or her in a timely manner. How can board performance no matter to corporate performan$c e ? »$.

${ }^{19}$ OECD. «Corporate Governance and the Financial Crisis: Key Findings and Main Messages». Junio 2009. En este informe puede leerse en el primer apartado contenido en la rúbrica «Effective Implementation of Risk Management»: «Perhaps one of the greatest shocks from the financial crisis has been the widespread failure of risk management». En el informe se consignan otros aspectos a los que debe prestarse especial atención: el sistema de remuneración de incentivos de los administradores; los indicios de responsabilidad 
Pero no solo ha sido deficiente la gestión de riesgos, sino que la estructura y composición de los Consejos de Administración hacía vulnerables a las grandes compañías. Se señalan como prácticas indeseables la coincidencia de las funciones de Chairman y de CEO; y el hecho de que gran número de Consejos funcionaran como auténticos clubes privados, donde las reglas del favoritismo y la reciprocidad en las recompensas están a la orden del día. La pregunta no es ahora ya «dónde estaba el Consejo» ${ }^{20}$, sino «dónde se encontraban los accionistas» para haber tolerado que las cosas llegaran a ese extremo.

El informe pone el dedo en la llaga cuando expresa que los Consejos de Administración, al desplegar la función de supervisión o monitorización que les incumbe, tienden a ser en épocas de vacas flacas más reactivos que proactivos. En suma, que en su función de supervisión se comportan cíclicamente. La supervisión es mínima cuando los resultados económicos acompañan y se torna de máxima intensidad cuando las cosas van mal. Esto significa que la función de supervisión se va a ejercer siempre a destiempo, ex post, y no previsoramente, lo que es tanto como llegar a la parada cuando el autobús ya ha partido.

En el informe también se proponen medidas radicales de cambio en el funcionamiento del Consejo. Al ser muy importante la independencia de los miembros, para lo sucesivo debería prestarse mayor atención a los aspectos de la competencia y de la dedicación exclusiva. En particular, los consejeros independientes en el sector bancario deberían tener dedicación full-time. En consecuencia, no es suficiente la actitud o el talante, sino que deben complementarse con la aptitud y el talento.

En este estado de cosas no es de extrañar que se levante un clamor coincidente que aboga por el reforzamiento de los deberes y la agravación de las responsabilidades de los consejeros. En suma, que se preconiza el reforzamiento de los principios del Gobierno Corporativo.

En estos tiempos de crisis se están produciendo algunos sucesos y procesos significativos que afectan a los principios de Gobierno Corporativo. Uno de ellos consiste en el incremento del número de Juntas Generales que se constata en los momentos difíciles, cuando los problemas y preocupaciones se acumulan. En el siguiente cuadro, que cubre una muestra de diecisiete países europeos, puede verificarse el referido fenómeno ${ }^{21}$.

apuntan a los Consejos de Administración; y la cuestión de si son los propios accionistas capaces de proteger sus respectivos intereses. En cualquier caso, el informe subraya que estas preocupaciones no son exclusivas de las empresas bancarias o entidades de crédito, sino comunes a todas las empresas con independencia de cuál sea su actividad.

${ }^{20}$ Macavoy, Paul V. y Millistein, Ira M., op. cit., páginas 86 y siguientes.

${ }^{21}$ El cuadro fue presentado por Caprase, Jean-Nicolas, European Governance Head, de RiskMetrics Group, durante la exposición de su ponencia «El Gobierno Corporativo y la crisis», que tuvo lugar en el Instituto de Empresa, Centro de Gobierno Corporativo, Madrid, 26 de noviembre 2009. 


\section{Voting results in Europe - 2009}

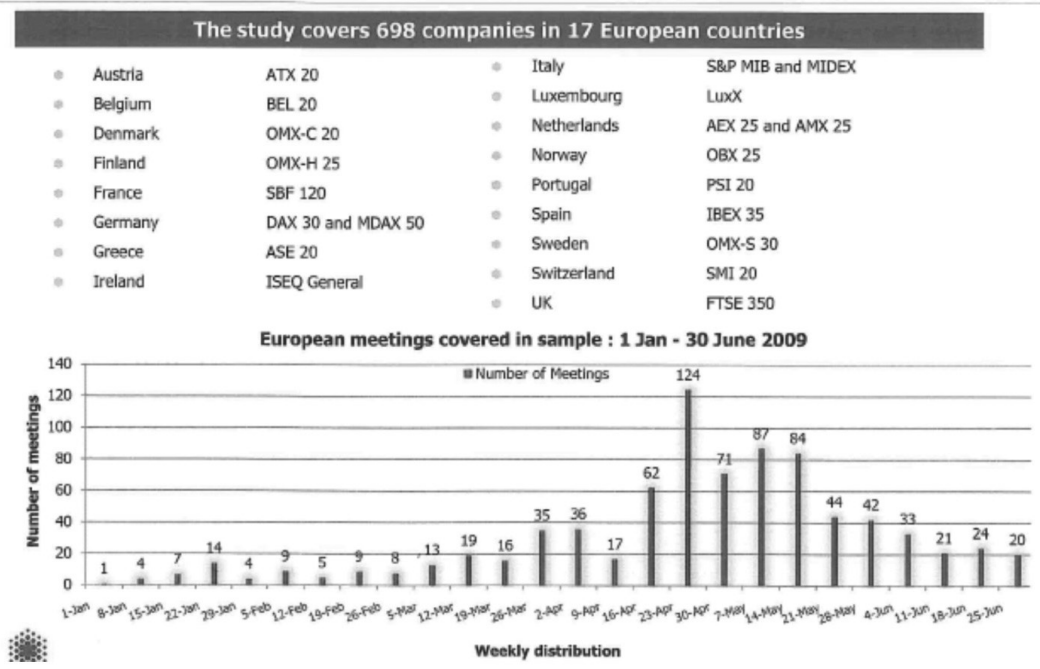

Del mismo modo, puede apreciarse que el grado de contestación de accionistas, o el número de accionistas disconforme con las propuestas que lleva para su deliberación y aprobación en la Junta el Consejo de Administración, ha ido en aumento.

\section{Relevant dissent per issue}

Nominations:

\begin{tabular}{|c|c|c|c|c|c|c|c|c|}
\hline Gauntos & Comeany & Iten & Dranosial & ROR & MGainsi & ABSTMIII & DISGFET & OUTREMIE \\
\hline UK & Ria Tiinto & 5 & Reelect Rod Eddington as director & $59.1 \%$ & $32.3 \%$ & $8.5 \%$ & $40.9 \%$ & Accepted \\
\hline France & Total & 9 & Reelect Daniel Bouton as director & $58.9 \%$ & $41.1 \%$ & $0.1 \%$ & $41.1 \%$ & Accepted \\
\hline Luxenbourg & Ance orMittal & 9 & Reelect Narayanan Vaghul as director & $93.2 \%$ & $6.8 \%$ & $0.0 \%$ & $6.8 \%$ & Accepted \\
\hline Luxembourg & Arce orMittal & 10 & Reelect Wilbur Ross as director & $91.7 \%$ & $8.3 \%$ & $0.0 \%$ & $8.3 \%$ & Accepted \\
\hline Luxembourg & Arce orthittal & 11 & Reelect Francois Pinault as director & $91.2 \%$ & $8.8 \%$ & $0.0 \%$ & $8.8 \%$ & Accepted \\
\hline
\end{tabular}

Fuente: Jean-Nicolas Caprase, European Governance Head, de RiskMetrics Group.

Por último, para completar la referencia a la relación entre el Gobierno Corporativo y la situación de crisis, cabe preguntarse cuáles son las preocupaciones que en el momento actual manifiestan los inversores institucionales, quienes, por su grado de profesionalidad y responsabilidad, es de suponer que tienen un criterio más racional y fundado sobre este punto. 


\section{Los aspectos más preocupantes}

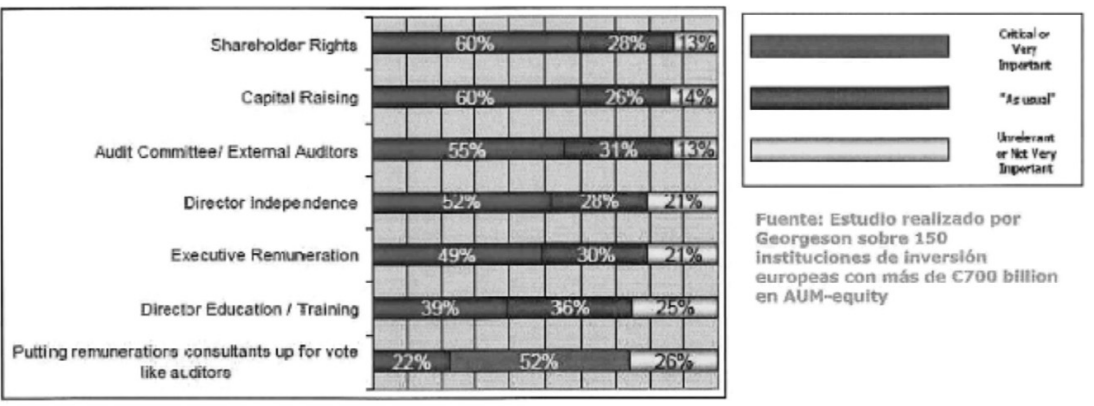

Fuente: Pedro Saá, «El Gobierno Corporativo y la crisis. La visión de los inversores institucionales». Noviembre, 2009.

A finales del año 2008, se formuló a los inversores institucionales la pregunta de si iban a reaccionar a la situación de crisis con mayores niveles de activismo y de control en las Juntas Generales de Accionistas de los ejercicios por venir. Las respuestas que dieron tales inversores no permiten alcanzar una conclusión bien definida. Al contrario, cabe pensar que no existe una visión uniforme sobre su actitud para los siguientes meses en asuntos de Corporate Governance, aunque continúan manteniendo la recurrente demanda de más supervisión y vigilancia y de mayor transparencia. También parece que los inversores institucionales serán más cautelosos en la política de delegación de su voto en el órgano de Administración. Los inversores, por otra parte, manifiestan que prestarán más atención a los asuntos estratégicos o de mayor importancia que se acometan en las compañías en las que toman posiciones. Por último, un tercio de los inversores institucionales prevé cambios en las políticas de ejercicio de voto, y este giro es más intenso en el Reino Unido y en Francia 22 .

${ }^{22}$ Los aspectos más preocupantes para los inversores institucionales en el campo del Gobierno Corporativo pueden representarse en el siguiente cuadro, en el que se emplea una escala sobre el grado de importancia o preocupación de cada una de las rúbricas consideradas; escala que periodifica la trascendencia del asunto en tres niveles: asuntos críticos o muy importantes; asuntos que tienen la importancia corriente o que siempre se les ha venido prestando; y asuntos irrelevantes o no muy importantes. 


\section{El despliegue temporal del programa del Gobierno Corporativo}

Entre nosotros ha sido Cándido Paz-Ares quien ha llevado a cabo una exposición convincente de los hitos o aspectos del Gobierno Corporativo que a lo largo del tiempo han ido reclamando mayor atención. En un primer momento, los instrumentos del Gobierno Corporativo se centraron en la constitución de un Consejo de Administración que tuviera alta capacidad de supervisión de los responsables ejecutivos de la compañía y en el establecimiento de un sistema de OPA $^{23}$ y de mecanismos de competencia para la obtención de delegaciones de voto que facilitaran la concurrencia por el control de la compañía. En una segunda fase de despliegue, la atención se centró en diseñar un sistema de remuneraciones y de incentivos capaces de hacer convergir los intereses de los managers y los de los inversores, a la vez de fomentar la concentración parcial de la propiedad y la centralización del control en manos de uno o varios accionistas de referencia con incentivos suficientes para vigilar a los administradores. En un tercer momento, ya en las vísperas de la actual crisis financiera y económica, se ha puesto el énfasis en definir la posición de los inversores institucionales como fuerzas preactivas

Toda la anterior información está tomada de la firma Georgeson, y fue elaborada para la presentación de la ponencia de Saá, Pedro, «El Gobierno Corporativo y la crisis. La visión de los inversores institucionales», que tuvo lugar en el Instituto de Empresa, Centro de Gobierno Corporativo, Madrid, el 26 de noviembre de 2009.

${ }^{23}$ La bibliografía sobre las OPA, Mergers o Take Over-Bids es inabarcable. Es recomendable el trabajo de Jovanovick, B. y Rousseau, P. «Mergers as realocation». NBER working papers, October 2002. Según los citados autores las operaciones de adquisición del control de las compañías o mergers a menudo se producen en oleadas. Una primera oleada puede situarse en los últimos años del siglo XIX, y a ella la denominan la oleada del establecimiento de los monopolios; una segunda se produjo en la década de los veinte del pasado siglo, y es la fase de la creación de economías de escala. Una tercera oleada se produjo en los ochenta, que fue la década de la codicia; y, en fin, el último movimiento de mergers que identifican los autores es el de la oleada motivada por la globalización y arranca en los últimos años de la década de los noventa. Aún cabría considerar si no nos encontramos en el preludio de una quinta ola de mergers, a la que podríamos bautizar como la de la «resaca de la crisis». Hacen notar los autores citados que estos ciclos de mergers suelen coincidir con shocks tecnológicos, tales como la electrificación en los felices años veinte o, incluso, recientemente Internet. Ello debe de ser porque, a pesar de que los adquirentes del control hagan sobreprecios o primas por hacerse con él, todavía consideran que tienen capacidad para crear valor. Ellos adquieren ventajas derivadas de las oportunidades que generan los cambios tecnológicos. Murthy, Narayana R. N., op. cit., se ha referido a un caso que genera perplejidad desde la óptica del Buen Gobierno Corporativo en relación con las OPA o mergers: «These days, it has become common for a CEO who argues strongly in favor of a certain merger or acquisition to expect a retention bonus, alter consumating the $M \& A$. This is oxymoronic. This practice simple does not make sense and has to stop». 


\section{llamadas a desempeñar un papel significativo en las Juntas de Accionistas ${ }^{24}$ y en la implantación de un sistema efectivo de responsabilidad de los admi- nistradores que venga precedido de una adecuada definición de sus deberes.}

${ }^{24}$ La legislación española sobre Instituciones de Inversión Colectiva ha venido a establecer la obligación de las Sociedades Gestoras de ejercer el derecho de voto correspondiente a las acciones incorporadas a las carteras y patrimonios que gestionan en los siguientes términos. Dispone el art. 46 de la Ley IIC 35/2003, de 4 de noviembre: «d) En relación con los fondos gestionados, reglamentariamente se establecerán aquellos supuestos en los que, en atención a la relevancia cuantitativa y al carácter estable de la participación del fondo en el capital de una sociedad, la sociedad gestora estará obligada a ejercer todos los derechos inherentes a los valores integrados en el fondo en beneficio exclusivo de los partícipes, especialmente el derecho de asistencia y voto en las Juntas Generales.// En todo caso, las sociedades gestoras deberán informar a los partícipes de su política en relación con el ejercicio de los derechos políticos inherentes a los valores que integren la cartera del fondo, justificando bien el no ejercicio del derecho de voto o bien el sentido del mismo. Asimismo, deberán dejar constancia de dicha política en los documentos informativos que se determinen».

En desarrollo del anterior precepto de la ley, el artículo 81 del Reglamento IIC, aprobado por RD 1.309/2005, de 4 de noviembre, apartado I) establece: «En cuanto a la obligación establecida en el artículo 46.1.d) de la Ley, la SGIIC estará obligada a ejercer, con especial atención al derecho de asistencia y voto en las Juntas Generales, todos los derechos políticos inherentes a los valores integrados en los fondos que aquella gestione, siempre que el emisor sea una sociedad española y que la participación de los fondos gestionados por la SGIIC en la sociedad tuviera una antigüedad superior a doce meses y siempre que dicha participación represente al menos el $1 \%$ del capital de la sociedad participada. Asimismo, en cualquier caso, la SGIIC deberá dejar constancia en el correspondiente informe anual de su política en relación con el ejercicio de los derechos políticos inherentes a todos los valores integrados en el conjunto de fondos que aquella gestione, siempre que el emisor sea una sociedad española».

Siguiendo estrechamente y en todo a Alba Fernández cabe afirmar que las normas transcritas constituyen uno de los cambios más llamativos que entre los introducidos por la Ley de IIC. La cuestión del papel de las IIC ya fue planteada por Sommer a principios de los noventa, en un estudio denominado «Gobierno Corporativo en los noventa: Managers vs. Inversores Institucionales». Se trata de superar la tradicional pasividad de los accionistas en las grandes sociedades, su progresiva tendencia a renunciar a cuestionar la dirección de la empresa social a través del ejercicio de sus derechos. Ello es una consecuencia de la dispersión del capital y se ha explicado desde los postulados del Análisis Económico del Derecho y de las «ciencias del comportamiento», que ven en tal actitud una «apatía racional», pues en un análisis costes-beneficios el accionista minoritario constata que carece de incentivos suficientes para implicarse en la vida de la Junta de accionistas con la finalidad de hacer valer sus derechos y tratar de contribuir a la mejora de la dirección del negocio social. Tal implicación en la vida social tiene un coste de oportunidad, que resulta de comparar dicha alternativa con la de negociación de las acciones de los mercados de valores y salirse de la compañía: el alto grado de liquidez de las acciones induce al socio inversor a abandonar la sociedad a través de su negociación en la Bolsa antes que a tratar de corregir la marcha de la sociedad en que se encuentra a disgusto mediante el ejercicio de sus derechos. A este factor se le conoce como la Wall Street Rule. En suma, las opciones entre las que permanentemente se mueve el accionista inversor son retener sus acciones, y permanecer en la sociedad como convidado de piedra, o marcharse negociándolas: hold or trade. 


\section{La etapa inicial del desarrollo del movimiento Corporate Governance, que tenía en su guión los dos primeros puntos que acaban de recordarse, es}

En el anterior panorama irrumpen las instituciones de inversión colectiva. Pueden optar por la pasividad o por la intervención en ejercicio de sus facultades como socios en un sentido concreto, quizás no alineado con los intereses gestionados. Un ejemplo que muy frecuentemente se cita es el interés que tienen determinadas IIC (por ejemplo, las sensibles por razón de su actividad al flujo de información, así, los fondos de inversión) en mantener una buena relación con el consejo de administración de la sociedad, o con el núcleo directivo. Buena relación en este caso, como se ve, es un eufemismo para expresar sumisión, y esta sumisión puede responder al deseo de no perder cierta información sobre la sociedad, pero también al de conservar las relaciones comerciales (y los ingresos consiguientes) que la institución pueda mantener con la sociedad participada, independientes y totalmente ajenos a la relación societaria, es decir, a la participación. Cabe recordar a este respecto los llamativos cambios de política seguidos por el Deutsche Bank, como depositario de acciones de uno de sus mutual funds, en la campaña y votación previas al acuerdo de la Junta General de Hewlett Packard que finalmente llevó a la fusión de esta última con la compañía Compaq.

La obligación legal de que las IIC ejerciten el derecho de voto se basa en su concepción como un activo integrado en la propia acción, en la medida en que presenta una clara vocación instrumental en la posición y posibilidades del socio para influir en las consecuencias de naturaleza y contenido económico o patrimonial del funcionamiento de la sociedad.

El deber de votar impuesto a las IIC parece incompatible con el principio de diversificación del riesgo que informa su actuación. Sin embargo, la recelosa partícula que en definiciones anteriores impedía a los fondos de inversión llegar a integrar participaciones que otorgasen la «mayoría política o económica» en sociedades del portafolio, y que formaba parte de la expresión del objeto especializado típico de los fondos, ha desaparecido la legislación actual. Pero esta supresión es solo aparente, pues tanto la LIIC como su Reglamento mantienen los niveles de diversificación «en origen» y «en destino» de la normativa anterior, además de que, en lo que a esta última se refiere, las limitaciones a la presencia del fondo en la sociedad participada en términos cualitativos adquieren un tono aparentemente más restrictivo. A pesar de haber sido extraída de la definición del fondo la referencia a este extremo, en la actualidad tanto la LIIC como su Reglamento especifican que la participación de los fondos en un emisor «en ningún caso» podrá ser tal «que pueda implicar la posibilidad de ejercer una influencia notable sobre dicho emisor» por parte de la SC.

La cuestión entonces estriba en precisar los confines de la «influencia notable». A este respecto ha de señalarse que la SG puede ostentar la gestión de participaciones en una sociedad muy superiores a los límites individuales impuestos a cada fondo o SICAV, sin que ello resulte en una violación de los límites del art. 38 del Reglamento IIC. El límite a la participación, por otro lado, y a diferencia de lo que sucede con los límites a la concentración de participaciones, está formulado en términos cualitativos, y no cuantitativos, como aquel que permite ejercer una «influencia notable». Queda así por determinar lo que sea esta influencia. Se trata de un concepto jurídico indeterminado; la ley no señala qué pueda significar «influencia notable» en el contexto de las normas que en este momento nos interesa, como tampoco establece orientación alguna sobre cuándo pueda presumirse su presencia.

¿Qué papel se espera de las sociedades gestoras de fondos en las Juntas Generales? En primer lugar, hay que partir de que los deberes de información que se imponen a las Sociedades Gestoras, como al resto de los actores de los mercados financieros, han acabado por consagrarse, como sabemos, como una de las herramientas principales que el legislador maneja para la protección, en nuestro caso, del inversor. En tal sentido, la labor que presumiblemente se encomienda a las Sociedades Gestoras con la imposición de los deberes de 


\section{típicamente anglosajona. En la fase intermedia es cuando se da la expansión del Gobierno Corporativo a la Europa continental, donde, a diferencia de Estados Unidos y Reino Unido, se constatan elevadas tasas de concentración}

voto y de información, no es otra que la de asumir una mínima vigilancia o fiscalización de la gestión del negocio social determinada por el statu quo en cada momento vigente en la Junta General, la Administración resultante y el ejercicio de sus funciones por parte, tanto de la Administración, como de la Dirección.

El modelo rector de la obligación de ejercitar los derechos políticos del socio se concentra en la regla del «exclusivo beneficio de los partícipes». ¿Y cuál es ese interés? ¡La maximización del valor del patrimonio gestionado, es decir, la maximización del rendimiento colectivo y, por consiguiente, también del individual! Mas hay que empezar por admitir que si el interés a que ha de responder la actuación de la SG es el de los partícipes inversores, este no siempre coincidirá con el interés social. Recordemos que el interés social, aunque ha sido un concepto muy discutido (donde pugnan la tesis contractualista y la institucionalista) ha acabado por inclinarse, de acuerdo con la tesis contractualista, con el interés común de todos los socios, lo que conecta con la idea del ánimo de lucro que está en el origen causal del contrato de sociedad. Una fórmula más depurada hace del interés social la promoción, generación o maximización del valor para el accionista, pero presuponiendo que la generación de valor encuentra como presupuesto la preservación de la continuidad de la empresa y requiere por ello una aproximación basada en el crecimiento sostenido y una visión largoplacista de la gestión, que de este modo matiza la noción hasta el punto de formular como «creación de valor a largo plazo». Además, la maximización del valor, que es el eje del interés social, ha de ser real, lo que significa que es el valor de la empresa, el valor económico acumulado en la sociedad y, por vía de consecuencia, correspondiente a cada una de sus fracciones o acciones, y no necesaria y simplemente la cotización bursátil de la acción lo que resulta relevante a estos efectos.

La valoración final que hace el autor citado de nuestra legislación de IIC con relación al ejercicio obligatorio del derecho de voto por las Sociedades Gestoras es que la medida legal es insólita. Es un caso único en que se impone a un socio el ejercicio de los derechos políticos de su participación para tutelar sus intereses. Pero no carece de ratio: se tutelan los intereses «de otros» (no de la Sociedad Gestora), de los inversores, lo que es conforme a la obligación de administrar sus inversiones y a la consideración del voto como activo financiero que, bien gestionado, contribuye a incrementar el valor de la inversión del cliente. Esto significará probablemente una «perturbación» en el modus operandi de las Gestoras, que hasta ahora venían aplicando modelos matemáticos, métodos de valoración de inversiones y tenían que desarrollar también destrezas adicionales en las tareas administrativas anejas. Ahora se introduce un deber que requiere de una dinámica muy diferente. La rigidez de los artículos 46 LIIC y 81 RIIC puede generar el problema de votos precipitados, autómatas o protocolizados. El País, 11 de octubre de 2006, daba cuenta del voto en contra del nombramiento de cuatro consejeros para el Consejo de REPSOL YPF porque «la propuesta no se detalló con la misma antelación que el resto de las que se sometieron a la Junta, lo que llevó a algunos fondos a rechazarla no por un desacuerdo de fondo, sino por la aplicación de sus propias reglas internas al respecto». En fin, pueden surgir distorsiones en la labor que se espera de las Sociedades Gestoras, que es la de actuar como «guardianes» del buen gobierno y de la buena gestión. A los efectos de implementar esta filosofía fiscalizadora el derecho de designar consejeros conforme al sistema de representación proporcional (en el caso de las Sociedades Gestoras preferentemente consejeros independientes), ex art. 137 LSA, sería una opción interesante. 
de propiedad (Garrido distingue, a estos efectos, dos sistemas de estructura del capital de las sociedades: el market system, de accionariado muy disperso, y en que las compañías apelan con mayor intensidad a la financiación a través de los mercados de valores; y el accionariado o capital por bloques, propio de la Europa continental, en que se produce esa concentración de participaciones en accionistas de referencia ${ }^{25}$. Y en la tercera de las fases descritas aún cabe precisar que en la agenda del Gobierno Corporativo anglosajón es donde se presta especial significado al papel de los inversores institucionales, y en el resto del mundo preocupa el régimen de los deberes y responsabilidades de los administradores.

Pero avancemos en el tiempo. Todo lo anterior es ayer ya. Fijemos la mirada en lo que constituye el tema de nuestro tiempo, del momento presente. En la actual situación de crisis económica y financiera, el Gobierno Corporativo ha puesto la gestión de riesgos en la cabecera de la agenda ${ }^{26}$. Se pretende que se trate de una efectiva gestión, y de una gestión además integral, superando la vieja concepción del mero «control interno» que en el ámbito

La experiencia, ¿qué resultados muestra? Que este activismo de las IIC forzado por la ley está dando lugar a la externalización de la actividad conectada a la obligación de votar (surgen así empresas especializadas en voting consulting) y a la ampliación de los servicios de rating, que ahora califican añadiendo el factor de la «calidad del gobierno corporativo» del emisor, esto es, el valor reputacional.

Todo lo expuesto lleva a pensar que de las dos obligaciones que establecen la Ley y el Reglamento de IIC, más que la de voto, la de información de la política seguida en el ejercicio del voto es fundamental. En general, siempre la información al inversor lo ha sido. Pero no solo debería alcanzar esta información, como resulta de la legislación, al partícipe del fondo -al que sí que hay que emitir un documento, de acuerdo con la normativa-, sino a todo el mercado.

A continuación se relaciona una bibliografía mínima sobre este asunto. Alba Fernández, M. «El deber de ejercicio de los derechos políticos del socio de las sociedades gestoras de fondos de inversión». Madrid. Ed. Marcial Pons, 2009. Fernández Atela, G. y Zunzunegui, F. «Derecho de voto e inversión colectiva», Revista de Derecho del Mercado Financiero, marzo 2005. <http://rdmf.wordpress.com>, pp. 1 y 2. Paz Arias, J. M. de. «Los inversores institucionales como medio de resolución del conflicto de intereses entre administradores y accionistas de la sociedad abierta». Revista de Derecho Bancario y Bursátil, n. ${ }^{\circ}$ 60, 1995, pp. 857-919.

${ }^{25}$ Mateu de Ros Cerezo, Rafael. El Código Unificado de Gobierno Corporativo. Ed. Thomson-Aranzadi. Cifur Menor, 2007. Y de este, conferencia no editada, «Los derechos de los accionistas significativos». I Jornada de Gobierno Corporativo, Instituto de Empresa, 26 de noviembre de 2009, Madrid.

${ }^{26}$ En la Ley del Mercado de Valores, con ocasión de la reforma en ella operada por la Ley de 2003, de Transparencia de las Sociedades Anónimas Cotizadas, ya se hacía una referencia explícita a este extremo, al establecer su art. 116 el contenido mínimo del Informe Anual de Gobierno Corporativo que venían obligadas a publicar las sociedades anónimas cotizadas. Figuraba en el apartado 4 d) los «Sistemas de control del riesgo». Claro que la referencia al «control» se queda muy lejos de una «gestión integral» de los riesgos, que es lo que ahora se preconiza. 
financiero se venía considerando desde comienzos de la década de los noventa. Los retos actuales de la gestión de riesgos alcanzan a una diversidad de dimensiones: la estrategia, el acceso a los mercados de capital y su coste, la mejora de la información, la reducción de costes y el aumento de la eficacia de las actividades de control (riesgo operativo), el desarrollo de respuestas inmediatas ante los riesgos emergentes, el cumplimiento normativo y los aspectos reputacionales (cabe recordar aquí lo que tantas veces ha repetido Warren Buffet: «Lleva veinte años construir una reputación y cinco minutos arruinarla. Si piensa sobre ello, hará las cosas de diferente manera»).

El foro económico mundial ha identificado una serie de riesgos globales y los ha clasificado en función de su probabilidad en pacto a través del siguiente mapa:

\section{Evolución de la Gestión de Riesgos}

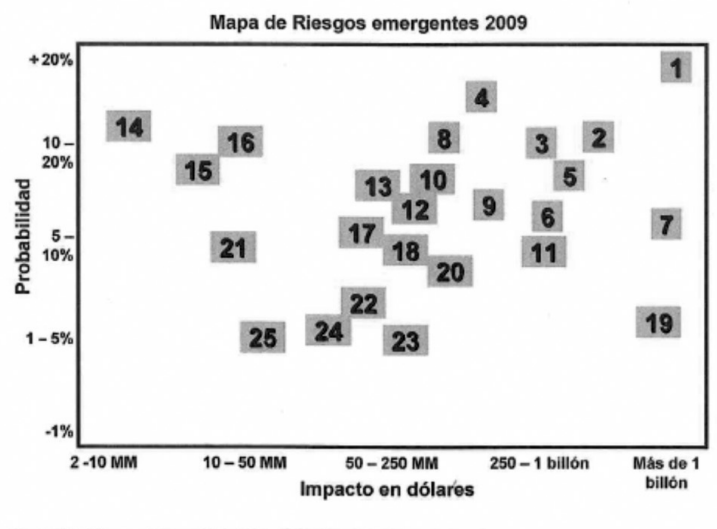

Euente: World Economic Fonum, Global Risks 2009: A Global Risk Network Report

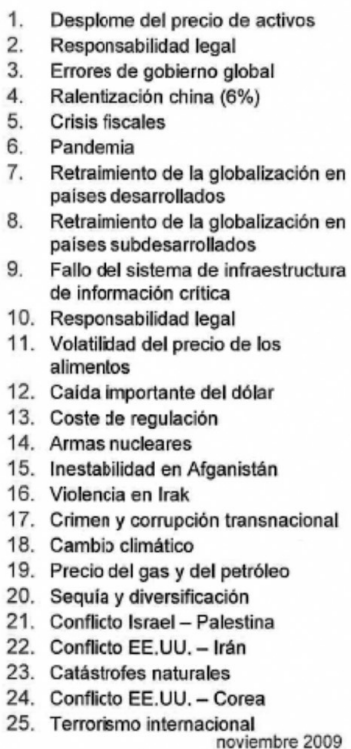

La importancia que ha adquirido la gestión de los riesgos en el actual contexto se puede apreciar analizando los recientes pronunciamientos de la Corte de Delaware, que pueden servir como estímulo y faro para otros tribunales. 


\section{Remodelando el régimen legal de los deberes y responsabilidades de los administradores}

El sistema del régimen legal de los deberes y responsabilidades de los administradores se presenta en la mayoría de los países como un auténtico rompecabezas. Entre nosotros, y sin perjuicio de que sea desarrollada la idea con otro detenimiento cuando el momento llegue, podríamos tratar de ordenar dicho sistema según tres ejes o vectores: el primer eje estaría constituido por la relación puntual de deberes que la legislación societaria y los estatutos de la compañía imponen a los administradores ${ }^{27}$; en segundo lugar, nos

${ }^{27}$ Solo dentro de la LSA encontramos varias decenas de obligaciones concretas de los administradores. Sin pretender ser exhaustivos enumeramos a continuación algunas de ellas:

informar a los accionistas sobre las adquisiciones a título oneroso en los dos primeros años de vida de la sociedad (artículo 41); velar por el desembolso de los dividendos pasivos (45 y 46); suscribir los títulos representativos de las acciones (53); llevar el libro-registro de acciones nominativas e informar a los accionistas en relación con sus acciones ( 55 y 56); cumplimentar las funciones relativas a la sustitución de los títulos (59); cumplir las obligaciones impuestas a la sociedad en materia de adquisición y tenencia de las propias acciones (74 y ss.), así como sobre las participaciones recíprocas (82 y ss.); convocar las juntas generales y fijar su orden del día (94, 97, 98 y 100), así como los relativos a determinados acuerdos específicos, como transformación, fusión, escisión, etc.; asistir a las juntas generales (104.3); subordinar la solicitud de representación a los accionistas a los requisitos formales requeridos (107.1); proponer la prórroga de la junta (109); atender el derecho de información de los accionistas (112); requerir la presencia del notario para que levante acta de la junta (art. 114); impugnar los acuerdos de la junta general (117.1) y del consejo de administración (143.1); deber de desempeñar el cargo con la diligencia de un ordenado empresario y de un representante leal (127); deber de guardar secreto sobre las informaciones de carácter confidencial (127.2); atender a la provisión interina de las vacantes producidas entre los miembros del consejo (138); establecer la regulación del funcionamiento del propio consejo y la delegación permanente de sus facultades (141); proponer la modificación de los estatutos sociales (144) y publicar los correlativos acuerdos (150); ejecutar el acuerdo de aumento de capital por delegación de la junta general y decidir el aumento del capital en los supuestos de capital autorizado (153); conceder el plazo a los accionistas para el ejercicio del derecho de suscripción preferente (158); elaborar la memoria justificativa del aumento de capital cuando se pida a la junta la supresión del derecho de suscripción preferente (159.1.); cumplir los requisitos y garantías exigidos para la reducción del capital social (165 y 166); rendir cuentas y formular, suscribir y presentar a la junta los documentos relativos a las cuentas anuales, el informe de gestión y la propuesta de aplicación del resultado (171 y ss., 175 y ss., 189 y ss, 199 y ss. y 202 y ss.); cumplir con el deber de la sociedad relativo a la información de sus accionistas (212.2); acordar el reparto de cantidades a cuenta de dividendos y formular un estado contable que acredite la suficiente liquidez (216); depositar las cuentas anuales en el Registro Mercantil (218 y 221); redactar y suscribir el proyecto de fusión o escisión (234); solicitar al Registrador mercantil la designación de expertos para que lo informen (236 a 256) y elaborar un informe explicativo y justificativo de estas (238 y 257), así como informar a la junta sobre sus modificaciones (238.2); convocar la junta en caso de disolución de la sociedad y pedir la disolución judicial si el acuerdo de la junta fuese contrario a la misma (262); prestar su 


\section{encontraríamos con aquellas normas sectoriales que también contemplan deberes y responsabilidades de los administradores; y, por último, enmarcan-}

concurso si fueren requeridos para la práctica de las operaciones de liquidación (267.2); y, en general, inscribir y dar la publicidad requerida a los acuerdos de la junta y, en su caso, del consejo.

A todos estos deberes habría que añadir lo que el resto de la legislación mercantil -especialmente el Código de Comercio en materia de contabilidad y registro, el Reglamento del Registro Mercantil y la Ley del Mercado de Valores para las sociedades cotizadas-, civil, fiscal y laboral configura como propios del órgano de administración en sus respectivas materias.

Por último, la Ley 3/2009, de 3 de abril, sobre Modificaciones Estructurales de las Sociedades Mercantiles, aunque no retoca las normas sobre deberes y responsabilidad de los administradores, sí afecta a algunas obligaciones concretas (información a los socios en caso de transformación, 9.1; redacción y suscripción del proyecto de fusión, 30.1; etc.) y da nueva redacción a muchos preceptos de la LSA en la Disposición Adicional, entre ellos algunos que hacen referencia a obligaciones de los administradores, como la del artículo 75.3.

A las anteriores obligaciones de los administradores deben añadirse las que contiene la legislación sectorial. Así, la Ley Concursal, 22/2003, de 9 de julio de 2003, al referirse a la calificación del concurso como culpable (artículos 164 y 165), al contenido de la sentencia de calificación (art. 172.2) y a la específica responsabilidad concursal de los administradores en el caso de concurso culpable con desenlace liquidatorio (art. 172.3), amén del régimen cautelar que contiene su artículo 48; la legislación en materia laboral; la legislación tributaria (artículos 42 y 43 de la Ley 58/2003, de 17 de diciembre, General Tributaria, que regulan, respectivamente, los casos de responsabilidad solidaria y subsidiaria); la legislación penal; y la Ley 26/2007, de 23 de octubre, de Responsabilidad Medioambiental. Esta última dispone en su artículo 13: «Los gestores y administradores de hecho y de derecho, incluso aunque hayan cesado en sus actividades, pueden ser responsables subsidiarios de los deberes en materia de responsabilidad medioambiental y, en particular, de las obligaciones pecuniarias. También pueden serlo los que sucedan al responsable en la titularidad o en el ejercicio de la actividad causante del daño, con determinados límites y excepciones; y, en ciertos casos, los liquidadores de administraciones concursales y los liquidadores de las personas jurídicas».

Sobre responsabilidad civil en general y extracontractual, imprescindible De Ángel, R. «La responsabilidad civil». Bilbao. Ed. Universidad de Deusto, 1988. Específicamente sobre responsabilidad de los administradores de sociedades: Arroyo, I., Embid Irujoi, J. M. y Górriz, C. (Coords). «Comentarios a la Ley de Sociedades Anónimas». Madrid, Ed. Tecnos, 2. a edición, 2009.- Idem. «Comentarios a la Ley de Sociedades de Responsabilidad Limitada». Madrid, Ed. Tecnos, 2. ${ }^{\text {a }}$ edición, 2009.- Cerdá Albero, F. «Responsabilidad civil de los administradores sociales: ¿Solos ante el peligro? Un análisis jurisprudencial (1990-2000)». InDret 1/2001.- Díaz Echegaray, J. L. «Deberes y responsabilidades de los administradores de sociedades de capital». Cizur Menor, Ed. Thomson-Aranzadi, 2. ${ }^{a}$ edición, 2006.- Llebot Majó, J. O. «La responsabilidad de los administradores de las sociedades mercantiles», (Directores Beltrán, E. y Rojo, A.), pp. 23-54. Valencia, Ed. Tirant lo Blanch, 3. a edición, 2009.- Marín Castán, F. «Sociedades Anónimas y de Responsabilidad Limitada». Madrid. Ed. La Ley, 2007, pp. 81-319.- Moya Jiménez, A. «Aspectos prácticos de la responsabilidad civil, mercantil y administrativa». Barcelona. Ed. Bosch, S. A., 2005.- Moya Jiménez, A. «La responsabilidad de los administradores de empresas insolventes». Barcelona. Ed. Bosch,

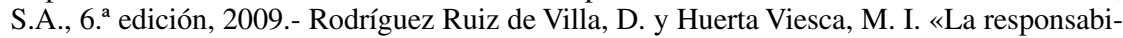
lidad de los administradores por las deudas de las sociedades de capital». Pamplona, Ed. Aranzadi, 2. ${ }^{\text {a }}$ edición, 2008.- Sánchez Calero, F. «Los administradores en las sociedades de capital». Navarra. Ed. Thomson-Civitas, 2. ${ }^{a}$ edición, 2007. 
do las dos categorías anteriores -que, reiteramos, tienen carácter corpuscular por razón de acopiar innumerables deberes particulares-, y como sinfonía de fondo, que cubre los amplísimos vanos que no pueden llegar a cubrir los dos ejes anteriores, aparecen los deberes generales o inherentes; esto es, los de diligencia (y formando parte de este, la obligación de informarse), el deber de fidelidad al interés social, el de lealtad y el de secreto de las informaciones de carácter confidencial. Estos son los deberes que figuran en el Real Decreto Legislativo 1.564/1989, de 22 de diciembre, por el que se aprueba el Texto Refundido de la Ley de Sociedades Anónimas, tras la reforma operada por la Ley 26/2003, de 17 de julio, por la que se modifican la Ley del Mercado de Valores y la Ley de Sociedades Anónimas con el fin de reforzar la transparencia de las sociedades anónimas cotizadas. Como ha podido decir un autor ${ }^{28}$, la reforma de 2003 constituyó un parto múltiple, pues del antiguo artículo 127 resultaron cuatrillizos: arts. 127, 127 bis, 127 ter y 127 quáter. Tal esponjamiento o split del originario artículo 127 vino a resolver algunos problemas de interpretación y a completar el régimen de los deberes de los administradores, pero, en contrapartida, suscitó cuestiones nuevas.

Interesa adelantar, no obstante, que nuestro régimen pasa a homologarse, casi miméticamente, con los de otros países de nuestro entorno; todos ellos se han puesto en la estela del modelo norteamericano, tal como venía siendo establecido por los tribunales.

El formato universal de los deberes de los administradores, común a una gran parte de ordenamientos nacionales, puede exponerse entonces del siguiente modo:

a) Así como los dos primeros vectores arriba señalados hacen referencia al «qué» de la obligación de los Administradores, los llamados deberes inherentes o generales (diligencia, fidelidad, lealtad y confidencialidad) significan el «cómo» deben comportarse los administradores en el desempeño de sus funciones. Interesa insistir en que no se trata de obligaciones coextensas. Ciertamente han de respetarse los deberes inherentes con ocasión de cumplirse las obligaciones puntuales o corpusculares que se definen en las leyes o en los estatutos de las sociedades. Pero estos son solo parte de los cometidos de los administradores, y fuera de ese piélago intersticial los administradores desempeñan una enorme variedad de funciones que no están tipificadas legal o estatutariamente, pero que inequívocamente pertenecen al ámbito propio de la función de administrar. Cuando el artículo 127.1 de la LSA, sobre el deber de diligente administración, establece que «los administradores desempeñan su cargo con la diligencia de un ordenado empresario y de

${ }^{28}$ Es indispensable, para un cabal seguimiento de este tema, leer a Font Galán, «El deber de diligente administración en el nuevo sistema de deberes de los administradores sociales». Revista de Derecho de Sociedades, núm. 25, 2005, páginas 71 a 107. 
un representante leal», es evidente que está señalando un ámbito de competencia que excede -y en mucho- a la relación de obligaciones puntuales, de carácter marcadamente formal, que se recogen en determinados preceptos legales o en los estatutos. La decisión de designar a un director financiero, de diseñar el plan estratégico, de acometer la absorción de otra compañía, de abordar una expansión geográfica, etc. no son deberes, pero sí cometidos imaginables que forman parte de la genérica función de administrar y de representar. Pues bien, también en este círculo de competencias materiales que exceden del inventario de deberes formales que resultan de la ley de los estatutos, los administradores deben atenerse al «cómo» que la ley establece como marco (diligencia, fidelidad, lealtad, confidencialidad), de suerte que en toda circunstancia en que aparezcan desempeñando su misión específica se conduzcan con esas diligencia, fidelidad, lealtad y respetando el secreto. Esta serie de cuatro deberes de actuación, según ya se ha indicado, se repite con ligeras variantes en los distintos ordenamientos nacionales de las sociedades mercantiles. Pero la estructura del sistema de deberes inherentes también se mantiene con la misma vocación general y se resume en la idea de que es el deber de diligencia el principal y estructurante de los demás, el que los ensarta y los vivifica con un nuevo y más intenso significado. Así, la dimensión proactiva del deber de diligencia consiste en cumplir los deberes impuestos por las leyes y los estatutos y, además, en conducirse en toda ocasión en el desempeño del cargo, con fidelidad al interés social, entendido como interés de la sociedad (art. 127 bis LSA); y la versión propasiva estribará en la observancia del deber de lealtad, que impide a los administradores utilizar el nombre de la sociedad o invocar su condición de tales para la realización de operaciones por cuenta propia o de personas a ellos vinculadas, y a abstenerse de realizar, en beneficio propio o de personas vinculadas, inversiones o cualesquiera operaciones ligadas a los bienes de la sociedad, de las que hayan tenido conocimiento con ocasión del ejercicio del cargo, cuando la inversión o la operación hubiera sido ofrecida a la sociedad o la sociedad tuviera interés en ella, siempre que la sociedad no haya desestimado dicha inversión u operación sin mediar influencia del administrador (art. 127 ter, LSA).

b) Puesta la atención ahora en los deberes inherentes o generales de los administradores, que son los que aquí interesan, procede señalar que tales deberes se definen según conceptos jurídicos indeterminados u open texture, por tomar la expresión de $\operatorname{Hart}^{29}$. Nuestra LSA, por ejemplo, se expresa con

${ }^{29}$ Hart, H. L. A. El Concepto de Derecho. Buenos Aires. Ed. Abeledo, Perrot, 2009, p. 159. «Cualquiera que sea la técnica, precedente o legislación, que se escoja para comunicar pautas o criterios de conducta, y por mucho que estos operen sin dificultades respecto de la gran masa de casos ordinarios, en algún punto en que su aplicación se cuestione las pautas resultarán ser indeterminadas; tendrán lo que se ha dado en llamar una "textura" abierta. Hasta aquí hemos presentado esto, en el caso de la legislación. Como una característica 
calculado laconismo en cuanto al significado del deber de diligencia de los administradores (art. 127.1, LSA), que solo llega a concretarlo en uno de sus haces, la obligación de informarse, a cuyo efecto dispone el 127.2 que «cada uno de los administradores deberá informarse diligentemente sobre la marcha de la sociedad». Ha recordado entre nosotros Font ${ }^{30}$ que este deber es individual y no un acto colectivo, como resulta de los términos claros de la ley: «Cada uno de los administradores...». Y añade el mismo autor que «el cumplimiento del deber y su correlativo ejercicio del derecho de informarse debe y puede acometerse en cualquier momento (y lugar)», lo que, añade, «quiere decir que no queda limitado ni por la convocatoria ni por la celebración de las reuniones del Consejo de Administración, lo que resulta concorde con el Código de Obligaciones Suizo, cuyo artículo 715 a) distingue entre la obligación de todo Administrador -e incluso de toda persona encargada de la gestión de suministrar información en las sesiones del Consejo de Administración (ap. 2) - y el derecho de todo administrador de exigir información de las personas encargadas de la gestión al margen de las sesiones del Consejo de Administración, tanto sea para conocer la marcha general de los asuntos sociales como para conocer asuntos u operaciones concretas (ap. $3) \gg$.

El empleo de términos open texture en los textos legales presenta a la vez ventajas e inconvenientes. La ventaja es que permite cierta flexibilidad y adaptación de la norma en su aplicación al caso concreto y facilita la interpretación evolutiva de la ley en los términos que establece el artículo 3.1 de nuestro Código Civil: «Las normas se interpretarán ... en relación con ... la realidad social del tiempo en que han de ser aplicadas atendiendo fundamentalmente al espíritu y finalidad de aquellas». El problema de los textos legales que emplean términos vagos o imprecisos es que producen incertidumbre en cuanto al resultado final, esto es, no permiten realizar una previsión fiable de lo que el juez hará en concreto en el caso que se pueda someter a su conocimiento. Recargar los cuerpos legales con normas de detalle produce una ossification del Derecho, pero posiblemente refuerza la seguridad jurídica que, no lo olvidemos, es un principio constitucionalmente garantizado (art. 9.3 CE). En cualquier caso, no parece superior la opción de llevar a la ley la definición más acabada posible de situaciones a que ha de aplicarse

general del lenguaje humano. La falta de certeza en la zona marginal es el precio que hay que pagar por el uso de clasificatorios generales en cualquier forma de comunicación relativa a cuestiones de hecho. Los lenguajes naturales -tal como el idioma inglés- muestran, cuando se los usa así, una irreducible textura abierta».

En relación con la función significante de los términos resulta inexcusable la consulta de Wittgenstein, L. Investigaciones filosóficas, Biblioteca de Grandes Pensadores. Ed. Gredos. Madrid, 2009. En especial, la deliciosa referencia a las fichas del ajedrez, páginas 193 y siguientes.

${ }^{30}$ Font Galán, J.I. Op. cit., páginas 105-106. 
cuando hacen referencia a realidades extraordinariamente vitales y dinámicas. La business judgment rule, que en los Estados Unidos opera en el ámbito de las decisiones judiciales, como creación de los tribunales, ha sido llevada en Australia al soporte legal ${ }^{31}$ sin gran beneficio.

c) De todo cuanto antecede resulta la importancia del rol que se atribuye a los jueces en la aplicación y concreción del Derecho. Sin poder llegar al extremo del realismo jurídico más acentuado, que encuentra su mejor exponente en el juez Oliver Wendell Holmes, para quien «Derecho es lo que deciden los jueces», ha de reconocerse que en este campo que consideramos ahora la palabra de los órganos jurisdiccionales tiene una relevancia muy notable. Ello es así porque manejan normas open texture y, además, porque no hay dos casos iguales que se sometan a su decisión ${ }^{32}$.

${ }^{31}$ Hernando Cebriá, L. El deber de diligente administración en el marco de los deberes de los administradores sociales. La Regla del-buen-juicio empresarial. Ed. Marcial Pons. Barcelona, 2009. Australian Corporations Act de 2001, 180: «Care and diligence-civil obligation only. Care and diligence-directors and other officers.

(1) A director or other officer of a corporation must exercise their powers and discharge their duties with the degree of care and diligence that a reasonable person would exercise if they:

(a) were a director or officer of a corporation in the corporation's circumstances; and

(b) occupied the office held by, and had the same responsibilities within the corporation as, the director or officer.

Note: This subsection is a civil penalty provision (see section 1317E).

Business judgment rule.

(2) A director or other officer of a corporation who makes a business judgment is taken to meet the requirements of subsection (1), and their equivalent duties at Common Law in equity, in respect of the judgment if they:

(a) make the judgment in good faith for a proper purpose; and

(b) do not have a material personal interest in the subject matter of the judgment; and

(c) inform themselves about the subject matter of the judgment to the extent they reasonably believe to be appropriate; and

(d) rationally believe that the judgment is in the best interests of the corporation.

The director's or officer's belief that the judgment is in the best interests of the corporation is a rational one unless the belief is one that no reasonable person in their position would hold.

Note: This subsection only operates in relation to duties under this section and their equivalent duties at common Law or in equity (including the duty of care that arises under the Common Law principles governing liability for negligence)-it does not operate in relation to duties under any other provision of this Act or under any other laws.

(3) In this section: business judgment means any decision to take or not take action in respect of a matter relevant to the business operations of the corporation».

${ }^{32}$ Cabe recordar aquí la concepción del Derecho de Dworkin, R. El imperio de la Justicia. Barcelona. Ed. Gedisa, 1988, para quien el proceso de creación y aplicación del derecho se asemeja a una novela escrita en cadena, en la que cada nuevo autor puede aportar algo original pero respetando el rumbo o el curso que han establecido cuantos le preceden. Esta metáfora telescópica de creación y realización del Derecho constituye un adecuado punto de partida para alcanzar varias certezas: 1) que el Derecho no se agota en el texto de la ley, 
No quedaría completa la exposición del asunto si no planteáramos una cuestión que, en razón de su importancia práctica, ha preocupado a la doctrina. Es la de la estratificación o diversificación de la responsabilidad de los administradores. Diversificación que opera en dos planos: el de los deberes entre sí; y el de las funciones de los administradores. En el primer aspecto, se trata de examinar si los deberes inherentes de diligencia y de lealtad (que son los de mayor trascendencia real) han de exigirse con severidad pareja; en el segundo, ha de considerarse si, debido a que las normas de Buen Gobierno Corporativo distinguen dos clases de miembros del consejo (los ejecutivos y, junto a ellos, los no ejecutivos que, a su vez, pueden ser accionariales o estrictamente independientes), a los que, en consecuencia, atribuye funciones también diferentes (la gestión recae en los ejecutivos, la supervisión en todos y, señaladamente, en los no ejecutivos), ha de exigirse a unos y a otros una diligencia distinta (por ejemplo, a los no ejecutivos se les hará responder de la culpa in omitiendo, in vigilando, in eligendo, in instruendo; y a los ejecutivos, además, de la culpa in comittendo). Y aún hacemos gracias de los problemas que se suscitan si parte de las funciones se delegan en comités y en cómo repercute ello en la responsabilidad de delegantes y delegados.

I) La discriminación de la exigencia según el deber incumplido

Hace unos pocos años Cándido Paz-Ares ${ }^{33}$ formuló entre nosotros la propuesta de diversificar el régimen de responsabilidad de los administradores. Construía su tesis tomando como punto de partida la existencia de un régimen unitario perturbador. Para él era de todo punto necesario «separar nítidamente la vertiente tecnológica (relativa a la producción de valor) y la vertiente deontológica (relativa a la distribución de valor) en que se descompone toda la actividad de gobierno de una empresa y, a partir de allí, elevar a categoría la distinción entre el deber de cuidado y el deber de lealtad». La conclusión que alcazaba la formulaba en la regla de la diferenciación: «el régimen de responsabilidad de los administradores ha de configurarse de modo que sea tan severo con las infracciones del deber de lealtad como indulgente con las infracciones del deber de diligencia».

bien porque la ley no lo prevé todo o bien porque sus términos no son suficientemente claros y redondos; 2) que el juez, en el trance de aplicación de la norma se va a ver casi siempre abocado a tomar su decisión final dando un «salto», desde el trampolín representado por la ley hasta el destino representado por la realidad sobre la que opera, y que ese salto puede ser de canguro o de pulga, en razón del grado de determinación que corresponda a la norma aplicable; y que así como la decisión jurídica -norma más sentencia- opera sobre una realidad, la realidad está operando constantemente sobre el significado de la norma y, en tal sentido, construyendo derecho. Al complejo norma-sentencia le precede la realidad, que se introduce en la decisión jurídica con ocasión de la definición del supuesto de hecho; pero no acaba ahí su función, sino que, además, en el trance de la aplicación de ese complejo norma-sentencia a la realidad esta está refluyendo sobre tal decisión y configurándola.

${ }^{33}$ Paz-Ares, C. Op. cit., pp. 14 y ss. 
Justificaba el autor la diversificación en una serie de consideraciones: la diligencia interesa tanto al accionista como al administrador (si no gestiona o la empresa va mal acabará perdiendo su fuente de ingresos y la oportunidad de mandar; su prestigio decaerá en el selecto tramo de mercado de trabajo en el que participa, etc.). Estos estímulos metalegales son lo suficientemente fuertes como para excitar el cuidado del administrador. No ocurre lo mismo con el deber de lealtad. Primero, porque los administradores, por la cuenta que les trae, ya se preocupan de que su conducta desleal no alcance visibilidad (tunnelling) ${ }^{34}$; segundo, porque las violaciones del deber de lealtad, los «pelotazos», suelen producirse en la fase epigonal de las relaciones de los administradores con la sociedad, y en estos momentos la disciplina que procuran las fuerzas del mercado está muy debilitada. Es decir, el incumplimiento del deber de lealtad no puede ser combatido eficazmente con la mera respuesta del mercado.

Las anteriores consideraciones llevaban a Paz-Ares a preguntarse cuál sería el nivel óptimo de rigor del régimen de responsabilidad de los administradores. Y se contestaba que para determinar ese nivel óptimo hay un factor relevante (no único, pero sí el decisivo), que es el grado de incertidumbre jurídica a que están sujetas las decisiones de los administradores, entendiendo por incertidumbre el hecho de que los administradores no pueden anticipar con seguridad cuáles serán las consecuencias jurídicas de tales decisiones. Las causas que provocan incertidumbres son las siguientes: (a) la ambigüedad del mandato legal (en cuanto que las obligaciones están definidas en la norma con frecuencia mediante términos open textu$r e)$. En este caso existe un margen de apreciación por el juez y, en consecuencia, también de error en la anticipación de lo que será la decisión judicial; (b) las dificultades de prueba; (c) las deficiencias de conocimiento del

${ }^{34}$ Paz-Ares recuerda la existencia de un índice significativo que puede resultar infalible para «sospechar» la posible existencia de deslealtad, cuya constatación, como queda dicho, es muy dificultosa porque tiende a enmascararse. Cuando el valor bursátil de una sociedad (es decir, el resultado de multiplicar la cotización de una acción por el número de acciones de una sociedad) posterior a la OPA de que haya sido objeto resulta menor de lo que ha estado dispuesto a pagar quien lanza la OPA para adquirir su control, ello solo puede ser debido, en buena lógica económica, a que la sociedad en realidad vale más para quienes pasan a ejercer el control. Esa diferencia de valor ha de consistir en la obtención de ventajas personales diferenciales que perciben los titulares del control en relación con el resto de los accionistas: contratos privilegiados con la propia sociedad, remuneraciones específicas, dietas, oportunidades de negocios, o incluso la remuneración de la vanidad (empire buildings). El diferencial más bajo entre ambos valores se registra en los países anglosajones (aproximadamente, un 2,5\%). En cambio, en España, la «prima de control» se situaba hace unos años en un 18,5\%. En suma, que parece razonable pensar que la prima de control se paga por razones no confesables y, en particular, porque el adquirente opera en un marco institucional que le permite obtener de la compañía más valor del que le corresponde por su participación en el capital. 
propio agente o errores del administrador en la determinación de la decisión correcta. Cabe distinguir a estos efectos, de acuerdo con Lonergan ${ }^{35}$, tres tipos de situación de riesgos: (a) los riesgos conocidos (que hacen referencia a aquellas situaciones para las que podemos plantear preguntas y darles respuesta); (b) los riesgos conocidos-desconocidos (situaciones ante las que podemos plantear preguntas -por lo tanto, el escenario es imaginable-, pero no tenemos respuesta); y (c) riesgos desconocidos-desconocidos (situaciones inimaginables: no solo carecemos de respuesta, sino que ni siquiera somos capaces de plantearnos la pregunta; y si hay otros que la formulan, carece para nosotros completamente de sentido o no tiene ningún interés la respuesta que pudiera recaer).

El temor de los administradores a incurrir en responsabilidad por actos que ellos no consideraron incorrectos cuando los decidieron o realizaron puede dar lugar al problema del «sobrecumplimiento» u overcompliance. El administrador que anticipa la posibilidad de error del juez extremará el celo adoptando precauciones por encima de las legalmente exigibles.

Tratándose de la responsabilidad por falta de diligencia, una normativa muy rigurosa puede introducir graves perturbaciones en la marcha de la empresa, y ello bajo dos aspectos: «conservadurismo» en la gestión y «murallas de papel». El fenómeno del «conservadurismo», producto de la aversión al riesgo, induce a los administradores a planificar las estrategias empresariales con un nivel de riesgo inferior al que convendría a los accionistas (estos, si han diversificado sus carteras, son neutrales al riesgo). Tal inercia conservadora, que empuja a los administradores a renunciar a proyectos de inversión altamente rentables (aunque entrañen riesgo) y a promover proyectos de inversión poco rentables (aunque de reducido riesgo) puede ir en contra de los intereses de los inversores. Y el problema se exacerba si el régimen de la responsabilidad de los administradores se vuelve más riguroso.

En cuanto a las «murallas de papel», son consecuencia de una aversión al riesgo que desencadena precauciones altamente ineficientes. Efectivamente, la exigencia de responsabilidad rigurosa conduce al administrador a rodear de barreras defensivas cualquier operación, a «amurallarla» con toda clase de papeles, dictámenes y opiniones de expertos, como ya se ha indicado con anterioridad en este trabajo. Ello puede representar un dispendio poco productivo de los recursos de la sociedad.

La conclusión para Paz-Ares es obvia: hay un error de defecto en el tratamiento de la deslealtad y un error de exceso en el tratamiento de la negligencia en el régimen de la responsabilidad de los administradores.

${ }^{35}$ Lonergan, B. (S. J.). Insight. Estudio sobre la comprensión humana. México. Ed. Sígueme y UIA, 1999 (2. ${ }^{\text {a }}$ edición, 2004). 
En punto al deber de lealtad o, en términos negativos, a la deslealtad, el mismo autor explica que son varias las razones de la inoperatividad de tal deber en nuestro derecho: (I) la insuficiente definición de las conductas desleales -lo que en parte se ha corregido con la introducción del art. 127 ter de la LSA por la reforma de la Ley de 2003, de Transparencia de las Sociedades Anónimas Cotizadas; (II) la insuficiente identificación de los destinatarios de los deberes de lealtad; (III) la insuficiencia de los cauces previstos para exigir la correspondiente responsabilidad; y (IV) la insuficiencia en el volumen de las sanciones aplicables.

Para que el sistema de la responsabilidad funcione es preciso contar con jueces dotados de formación específica y experiencia, que vayan más allá del planteamiento formalista del Derecho. Han de tener «cultura empresarial»o sensibilidad, como la tenía el Consejo de Estado Francés al tratar asuntos administrativos. Además, si ha de operarse con conceptos open texture, la seguridad jurídica aconseja que exista un stock suficiente de precedentes judiciales que haga previsible la decisión del juez y reduzca la incertidumbre. En nuestro país, e incluso en otros países vecinos de Europa, observamos una escasísima litigiosidad en materia de deber de lealtad. La pobreza y debilidad que exhiben nuestros sistemas jurídicos en este campo se deben en buena parte a la falta de oportunidades de que han dispuesto los jueces para crear un repertorio de precedentes y orientaciones en materia de responsabilidad.

Luego están las barreras procedimentales: el accionista que quiera litigar en España tiene que obtener primero una resolución de la Junta General que deniegue el ejercicio de la acción por la sociedad y, además, ha de ostentar al menos (y nada menos) que un 5\% del capital social (art. 134, LSA). Por ello no estaría contraindicado abrir nuevas vías de solución a los conflictos de responsabilidad: mediación, como se está ensayando en la Corte de Delaware desde hace unos pocos años; arbitraje, etc.

Paz-Ares recomienda, para reforzar la responsabilidad por deslealtad que «en caso de duda acerca del cumplimiento del deber de lealtad, la carga de prueba corresponda al administrador», ya que es un insider y está en situaciones de asimetría con el demandante para justificar que no ha incurrido en deslealtad. Según el mismo autor, habría que reforzar las sanciones asociadas a la deslealtad, e indica que las sociedades podrían incorporar a sus estatutos, a estos efectos, cláusulas penales garantizadoras del cumplimiento de los deberes de lealtad.

Por último, la percepción de que se ha endurecido la responsabilidad por negligencia de los administradores (la reforma de la LSA de 1989 suprime la franquicia por culpa leve, establece la responsabilidad solidaria, reduce del 10 al 5\% el porcentaje de capital necesario para ejercitar la acción de responsabilidad, elimina la posibilidad de excluir la responsabilidad mediante autorización o ratificación por la Junta del acto lesivo, etc.), ha llevado en ocasiones a la «colateralización» de la responsabilidad, es decir, a endosársela a un tercero vía contrato de seguro. 
La mayor benevolencia en el trato que ha de dispensarse a los fallos de diligencia ${ }^{36}$ conduce a indagar si cabe reconocer un ámbito de inmunidad a los administradores, esto es, de discrecionalidad ${ }^{37}$ de sus decisiones empre-

${ }^{36}$ Recuerda Paz-Ares, op. cit., un caso sobre los efectos perversos a que puede conducir la exigencia de una diligencia desmesurada a los administradores y sobre la inmediata rectificación de tal política de endurecimiento.

A finales de los años ochenta en los Estados Unidos se produjo una ola de fusiones y adquisiciones y el frenesí de operaciones de reestructuración que sacudió aquel mercado generó una elevada tasa de litigiosidad, lo que se saldó con un endurecimiento por parte de los Tribunales de la aplicación de la normativa legal y, en particular, de las exigencias de la Business Judgement Rule. Como consecuencia de ello sobrevino una crisis sin parangón de la industria del seguro de responsabilidad civil. La reacción frente a esa tendencia no se hizo esperar. Los Estados reformaron sus leyes de sociedades con el fin de limitar la exposición de los consejeros a riesgos de responsabilidad y ampliar sus derechos a ser indemnizados por la sociedad. La reforma más popular fue la del Estado de Delaware, que desreguló totalmente en 1986 la responsabilidad por negligencia (y en los dos años siguientes les secundaron otros 41 Estados de la Unión). La reforma permitió modificar los Estatutos de las sociedades para eliminar la responsabilidad de los consejeros por los daños negligentes y ellos se hizo sin oposición de los accionistas y sin destrucción de valor. La evidencia empírica con que contamos así lo acredita: los precios del mercado no experimentaron ningún impacto negativo cuando las sociedades anunciaron sus propósitos de reformar sus Estatutos para rebajar el duty of care o cuando sus Juntas Generales adoptaron los correspondientes acuerdos.

${ }^{37}$ El término discrecionalidad no es privativo del Derecho Mercantil, sino que constituye una de las rúbricas fundamentales -y más apasionantes- del Derecho administrativo. En este constituye todo un desafío para el especialista porque concentra de manera dramática todas las dificultades que entraña el sujetar la Administración al Derecho a través de un sistema de control y enjuiciamiento eficaz de su actividad, pero de tal forma que no se comprometa la eficacia con que han de quedar servidos los intereses generales. Tal vez por eso el juez del Tribunal Supremo americano Antonin Scalia haya podido afirmar que el derecho administrativo no es un Derecho para pusilánimes -el calificativo original, sissies es más expresivo, pero está justificado el eufemismo en aras de la integridad del papel soporte de este artículo y del buen nombre de la revista-. La referencia está tomada de Schwartz, Bernard. «Shooting the piano player? Justice Scalia and Administrative Law». Administrative Law Review, American Bar Association, 1995, pág. 1 (la cita) y siguientes hasta la 57.

Entre la discrecionalidad administrativa y la discrecionalidad de los administradores de las sociedades mercantiles existen evidentes analogías, pero también alguna dependencia. Son tantas las primeras que, hasta cierto tramo del análisis comparado, se podrían establecer consideraciones generales comunes. Efectivamente, en ambos casos actúan administradores o servidores de intereses ajenos: la Administración Pública y los administradores societarios; su función se orienta a la gestión de intereses supraindividuales (ya los intereses generales, en la fórmula del art. 103.1 in fine de la Constitución española, y al «interés social», que se define en el art. 127 bis LSA como el interés de la sociedad); en ambos casos se pretende acotar espacios de inmunidad de la actividad de los administradores frente al control o fiscalización judicial, pero con aparente (y añadiría que «solo aparente») distinta intención: en el caso de la discrecionalidad administrativa impedir la eventual declaración de ilegalidad de la actuación; en el ámbito mercantil bloquear una demanda de responsabilidad civil o por daños dirigida contra los administradores. Fuera de esto la finalidad a que obedecen una y otra especie de discrecionalidad difiere, como se podrá advertir cuando 
sariales. A tal efecto cabe partir de una clasificación de los casos de negligencia en cinco grandes categorías, que ordenamos en función de su gravedad creciente: (a) casos de deficiencia de juicio: valoraciones incorrectas y equivocaciones técnicas; (b) no haberse informado adecuadamente los administradores; (c) no haber observado los protocolos establecidos o los procedimientos previstos para la adopción de decisiones; (d) haberse conducido con actitud perezosa e indolente (dejadez, «consejeros de adorno»o «consejeros pasivos»); y (e) casos de deficiencia de imparcialidad, o presencia de algún interés personal en las decisiones (aquí nos acercamos a la deslealtad). Pues bien, en relación con el caso $a$ ), deficiencias de juicio, los tribunales americanos desde hace tiempo vienen construyendo un espacio de exención al enjuiciamiento a favor de los administradores. Se trata de la regla, tantas veces mencionada en el presente trabajo, del buen juicio empresarial o Business Judgement Rule, que más adelante desarrollaremos con alguna atención.

II) Hay, además, según anunciábamos, un segundo factor de estratificación de la responsabilidad de los administradores, en razón del tipo de funciones que se les asignan ${ }^{38}$. Supuesto que a no todos les corresponden igua-

se explique más adelante cuál es el fundamento racional del blindaje frente al control judicial. Por otra parte, las fronteras verbales que delimitan los espacios de inmunidad se construyen por la norma mediante una profusa utilización de términos open texture, como más adelante tendremos ocasión de desarrollar. Se relaciona a continuación una sumarísima bibliografía sobre la discrecionalidad administrativa. Cassagne, Juan Carlos. «La discrecionalidad administrativa y el control judicial». La Ley, 8 de septiembre de 2008, Año LXXII N. ${ }^{\circ} 172$. Coviello, Pedro J. J., «El control judicial de la discrecionalidad administrativa», Cuestiones del contencioso administrativo, publicación de las VII Jornadas Hispano-Argentinas de Derecho Administrativo, Lexis Nexis, Buenos Aires, 2007, pp. 271272. Cano Campos, Tomás. «La actividad de las Administraciones Públicas», Tomo III, Volumen I, «La forma», Iustel, Madrid, 2009 (vid. en particular Lección 1, «Las potestades administrativas», Bacigalupo Saggese, Mariano, págs. 14 a 41, especialmente a partir de la 25). Halliday, Simon. «Judicial Review and compliance with administrative law». Oxford and Portland, Oregon: Hart Publishing, 2004, pp. 188 y ss. Muñoz Machado, Santiago, Tratado de Derecho Administrativo y Derecho Público general, T I, cit., p. 459 y ss. Rana, Shurti. «Streamlining the Rule of Law: How the Department of Justice is Undermining Judicial Review of Agency Action». 82 University of Illinois Law Review 2009. Schwartz, Bernard, Administrative Law, 3. ${ }^{\text {a }}$ ed., Little Brown and Company, Boston, Toronto, Londres, 1991, p. 652.

${ }^{38}$ Alonso Ureba, A. «Diferenciación de funciones (de supervisión y dirección) y tipología de consejeros (ejecutivos y no ejecutivos) en la perspectiva de los artículos 133.3 (responsabilidad de los administradores) y 141.1 (autoorganización del consejo) del TRLSA». Ed. Thomson-Aranzadi. Revista de Derecho de Sociedades, n. ${ }^{\circ} 25,2005$, pp. 19-69. Contiene una amplia panorámica del debate en Europa sobre la cuestión.

Sánchez-Calero Guilarte, J. «Gran Bretaña: sentencia sobre la diligencia exigible a los consejeros independientes». Revista de Derecho Bancario y Bursátil, n. ${ }^{\circ}$ 100, 2005, pp. 252-256. El autor da cuenta de la sentencia recaída en un caso que enfrentaba a la Administración Pública con dos administradores, tomado las referencias de la autora Howell, C. 
les funciones, cada uno ha de responder de acuerdo con la doctrina evangélica de los talentos recibidos. Por referirnos a los cometidos más evidentes, gestión y supervisión, es claro que los administradores ejecutivos deberán responder por el incumplimiento de las obligaciones inherentes a las tareas gestoras y aquellos a los que se encomendó la vigilancia, por la quiebra de los mismos deberes (diligencia, fidelidad, lealtad, secreto) conectados a esta actividad de «monitorización» ${ }^{39}$.

«Secretary of State v. Swan and North», J.B.L. septiembre 2005, pp. 640-647. En un marco legal de creciente exigencia de responsabilidades a los consejeros independientes en relación con sus deberes de supervisión se produjeron los siguientes hechos: el Sr. Swan era $\mathrm{CEO}$ de una sociedad cotizada, que formaba parte de un grupo empresarial. Firmó una serie de cheque, entre dos sociedades pertenecientes a dicho grupo por importantes cantidades. En el plazo que medió entre el libramiento y su compensación bancaria el valor de los cheques aparecía contabilizado doblemente, como activo de las dos sociedades. En esas fechas se produjo la venta de otra filial del mismo grupo. Esta operación de venta requería que se aportara una declaración a los accionistas acerca del endeudamiento de las compañías. La operativa de los cheques afectaba a la validez de esta información. El Sr. North era un consejero independiente, presidente además del Comité de Auditoría y Retribuciones. Tenía amplia trayectoria como consejero y especial preparación en asuntos de contabilidad. Cuando un ejecutivo de la compañía le advirtió de la posible irregularidad, se contentó con mantener una breve reunión con el presidente Sr. Swan y con el responsable financiero, sin realizar averiguaciones complementarias que le hubieran permitido descubrir la manipulación de los cheques. El juez fue especialmente severo con su actitud. Era un momento en que cabía esperar del Sr. North, de un consejero independiente, que actuara con criterio propio, decisión y valentía, que le llevara a enfrentarse, si resulta necesario, con sus propios compañeros, en lugar de «mirar para otro lado».. Howell apostilla: «Mr. North was not dishonest and he had done nothing wrong, but that was the problem, he had done nothing».

${ }^{39} \mathrm{El}$ fundamento legal de tal conclusión es entre nosotros bastante evidente. Baste recordar que el art. 1.104 del Código Civil -en sede de responsabilidad derivada de culpa en el cumplimiento de las obligaciones- dispone en su primer párrafo: «La culpa o negligencia del deudor consiste en la omisión de aquella diligencia que exija la naturaleza de la obligación y corresponda a las circunstancias de las personas, del tiempo y del lugar». La referencia a la «naturaleza de la obligación permite sostener que la función específica de cada administrador modela la medida de la diligencia que le es exigible. Aún hay una referencia legal más próxima materialmente, pues se encuentra en el ámbito del Derecho de Sociedades. Cuando la Ley 19/2005, de 14 de noviembre, sobre la sociedad anónima europea domiciliada en España, añade a la LSA los artículos 312 y ss., contempla la posibilidad de que tal tipo de sociedades opten en los estatutos por un sistema de administración monista o dual (art. 327). En el sistema dual existirá una dirección y un Consejo de control (art. 329), encargada la dirección de la gestión y representación de la sociedad (art. 330.1). Al Consejo de control le corresponde la misión que su propio nombre sugiere y podrá acordar tal Consejo que determinadas operaciones de la dirección se sometan a su autorización previa (art. 334). Pues bien, al regular el art. 335 LSA la responsabilidad de los miembros de los órganos de administración, contiene una previsión de «exigir a cada cual según lo que debe» en términos inequívocos: «Las disposiciones sobre responsabilidad previstas para los administradores de sociedades anónimas se aplicarán a los miembros de los órganos de administración, de dirección y del Consejo de control en el ámbito de sus respectivas funciones». No podía ser de otro modo. 
Como sinfonía de fondo del régimen legal de los deberes de los administradores debe subrayarse que su acción ha de ir siempre encaminada a la realización del interés social. Este concepto, ciertamente necesitado de precisión o definición depurada en el caso concreto, da rumbo, orientación o «sentido» a los deberes inherentes o generales. No es lugar para regodearnos en examinar morosamente el concepto de interés social. Baste decir, a nuestros efectos, que la Ley de Transparencia de 2003, al incorporar el nuevo art. 127 bis a la LSA, declaró que el interés social es el «interés de la sociedad», lo que parece aludir a la idea del interés común de los accionistas. El Informe Olivencia había expresado con anterioridad que el interés social coincide con la maximización del valor de la empresa a largo plazo.

La fórmula legal no deja de ser enigmática. Hay que admitir que muchas veces «el recurso a fórmulas ambiguas se convierte en una necesidad política, ya que constituyen la única estrategia que permite presentar el disenso como consenso» ${ }^{40}$.

Es sabido que hay dos concepciones fundamentales sobre el interés social: (a) la tesis contractualista, para la que el interés social consiste en el interés de los accionistas; y (b) la tesis institucional, para la que el interés social es el de la empresa, en el que se conciliarían y se sintetizarían los intereses no siempre convergentes de los distintos grupos que en ella participan: accionistas, trabajadores, proveedores, clientes, comunidad local, etc. Esta segunda concepción institucionalista conecta la noción de interés social con la de «responsabilidad social corporativa $»^{41}$, aludida con anterioridad en el presente trabajo.

\section{El papel de los jueces. Un caso ejemplar. la sentencia Citigroup de la Corte de Delaware}

Se trata de una de las más tempranas decisiones que sobre una compañía afectada por la crisis ha adoptado la Corte de Delaware. En ella se apli-

\footnotetext{
${ }^{40}$ Paz-Ares. Op. cit., p. 122.

${ }^{41}$ Añade Paz-Ares, op. cit., pp. 123 y 124, que, en cualquier caso, la formulación del interés en términos de maximización del valor de la empresa parece una directriz neta y clara que proporciona al órgano de administración de la sociedad y a las instancias ejecutivas sujetas a su supervisión un buen criterio para adoptar decisiones y evaluar el cumplimiento de objetivos.

Por otro lado, este criterio que pone la atención en el interés de los accionistas está lejos de despreciar los intereses de los demás colectivos (clientes, trabajadores, etc.), pues hay que tener en cuenta en este sentido que los accionistas perciben la renta residual de la empresa (lo que queda después de pagado lo debido a los demás) y soportan por ello su riesgo residual y, por tanto, el arreglo de sus intereses pasa necesariamente por la previa satisfacción de lo contractualmente prometido a los demás. Los accionistas son, desde este punto de vista, los titulares de las inversiones más vulnerables.
} 
ca el criterio tradicional de la BJR. Se desestima la responsabilidad de los administradores por «riesgo del negocio» y defecto de «monitorización»o vigilancia, pero se da curso a la reclamación que persigue reducir las compensaciones, primas y demás emolumentos reconocidos al CEO saliente.

Los accionistas habían promovido una derivative litigation o stockholder's derivative suit ${ }^{42}$ (esto es, en beneficio de la sociedad) contra una larga serie de administradores y altos ejecutivos de la compañía, basándose en los siguientes fundamentos: primero, el incumplimiento de sus deberes fiduciarios por defectos de monitorización o vigilancia y de gestión de los riesgos asociados al mercado de las hipotecas subprime, y por haber emprendido una serie de actividades injustificadas que depararon grandes pérdidas a la compañía. Los demandantes alegaron la doctrina Caremark por haberse incumplido el deber de vigilancia y gestión de los riesgos asociados al mercado de las hipotecas subprime y por haber ignorado las red flags o señales de alerta que manifiestamente advertían al Consejo de los riesgos existentes. Tales banderas rojas incluyen artículos de opinión en prensa, bancarrotas de filiales y otra información pública disponible desde el 2005 que reflejaba el empeoramiento de las condiciones de los mercados financieros, incluyendo el de hipotecas subprime, y las enormes pérdidas experimentadas por compañías comparables a City, como Bear Stearns y Merrill Lynch. Los demandantes apuntaron el hecho de que la mayoría de los administradores de Citigroup eran expertos financieros, que ya deberían haber escarmentado por su proximidad e intervención en el no tan lejano asunto Enron, y tendrían que haber estado especialmente sensibles a las señales del mercado y a los peligros que presentaba la inversión, que a la postre resultó en gran medida fallida, en «vehículos estructurados de inversión» $(\mathrm{SIV})^{43}$.

${ }^{42}$ Se corresponde con la acción de responsabilidad social del artículo 134 de nuestra LSA que, como es sabido, persigue resarcir el daño experimentado por la propia sociedad y la legitimación activa se articula según un sistema «en cascada» o sucesivo: primero está legitimada la propia sociedad; en su defecto o por falta de voluntad de la propia sociedad, se hallan legitimados accionistas que representen al menos un 5\% del capital; en última instancia, subsidiariamente, los acreedores de la sociedad, siempre que el patrimonio de esta resultare insuficiente para la satisfacción de sus créditos. Nada que ver, por tanto, con la acción individual contemplada en el art. 135 LSA, cuyo fundamento se encuentra en la lesión de los propios intereses de los socios o de los terceros, y no de la sociedad.

${ }^{43}$ In Re Citigroup Inc. Shareholder. Civil Action No. 3338-Cc Derivative Litigation. Conviene reproducir con la extensión que se merece la doctrina del tribunal porque constituye un compendio actualizado de su doctrina. Al objeto de facilitar el seguimiento, en razón de su longitud, seleccionamos los aspectos más relevantes de la selección que hacemos del texto, rubricando los contenidos más significativos:

Alegaciones de los demandantes «Plaintiffs' Claims. Plaintiffs allege that defendants are liable lo the Company for breach of fiduciary duly for (1) failing lo adequately oversee and manage Citigroup's exposure lo (he problems in the subprime mortgage market, even in the face of alleged "red flags" and (2) failing lo ensure that the Company's financial reporting and other disclosures were thorough and accurate. As will be more fully explained below, 


\section{La Corte de Delaware rechazó la pretensión de que la demanda fuera} enjuiciada a la luz de la teoría Caremark (que se aplica característicamente

the "red flags" alleged in the eighty-six page Complaint are generally statements from public documents that reflect worsening conditions in the financial markets, including the subprime and credit markets, and the effects those worsening conditions had on market participants, including Citigroup's peers. By way of example only, plaintiffs' "red flags" include the following:

May 27, 2005: Economisi Paul Krugman of the New York Times said he saw "signs that America's housing market, like the stock market at the end of the last decade, is approaching the final, feverish stages of a speculative bubble".

May 2006: Ameriquest Mortgage, one of the United States' leading wholesale subprime lenders, announced the closing of each of its 229 retail offices and reduction of 3,800 employees.

February 12, 2007: ResMae Mortgage, a subprime lender, filed for bank ruptcy. According lo Bloomberg, in its Chapter 11 filing, ResMae stated that "[t]the subprime mortgage market has recently been crippled and a number of companies stopped originating loans and United States housing sales have slowed and defaults by borrowers nave risen".

April 18, 2007: Freddie Mac announced plans to refinance up to $\$ 20$ billion of loans held by subprime borrowers who would be unable to afford their adjustable-rate mortgages at the reset rate.

July 10, 2007: Standard and Poor's and Moody's downgraded bonds backed by subprime mortgages.

August 1, 2007: Two hedge funds managed by Bear Stearns that invested heavily in subprime mortgages declared bankruptcy.

August 9, 2007: American Internacional Group, one of the largest United States mortgage lenders, warned that mortgage defaults were spreading beyond the subprime sector, with delinquencies becoming more common among borrowers in the category just above subprime.

October 18, 2007: Standard \& Poor's cut the credit ratings on $\$ 23.35$ billion of securities backed by pools of home loans that were offered to borrowers during the first half of the year. The downgrades even hit securities rated AAA, which was the highest of the ten investment grade ratings and the rating of government debt.»

Correcta aplicación por el tribunal de primera instancia de la regla del buen juicio empresarial (BJR): «...g analyzing these claims, the Court began, appropriately, by reviewing the duty of tare and the protections of the business judgment role. With regard to director liability standards, the Court distinguished between (1) "a board decision that results in a loss because that decision was ill advised or 'negligent"” and (2) "an unconsidered failure of the board to act in circumstances in which due attention would, arguably, have prevented the loss. 40 In the formerclass of cases, director action is analyzed under the business judgment rule, which prevents judicial second guessing of the decision if the directors employed a rational process and considered all material information reasonably available - a standard measured by concepts of gross negligence. 41 As former-Chancellor Allen explained: What should be understood, but may not widely be understood by courts or commentators who are not often required to face such questions, is that compliance with a director's duty of tare can never appropriately be judicially determined by reference to the content of the board decision that leads to a corporate loss, apart from consideration of the good faith or rationality of the process employed. That is, whether a judge or jury considering the matter after the fact, believes a decision substantively wrong, or degrees of wrong extending through "stupid" to "egregious" or "irrational", provides no ground for director liability, 


\section{a los fallos de detección y prevención de conductas criminales o fraudulen- tas de los empleados) y concluyó que el error de los administradores en el}

so long as the court determines that the process employed was either rational or employed in a good faith effort lo advance corporate interests. To employ a different rule-one that permitted an "objective" evaluation of the decision-would expose directors substantive second guessing by ill-equipped judges or juries, which would, in the long-run, be injurious lo investor interests. Thus, the business judgment rule is process oriented and informed by a deep respect for all good faith board decisions. In the latter class of cases, where directors are alleged lo be fiable for a failure lo monitor liability creating activities, the Caremark Court, in a reassessment of the holding in Graham, stated that while directors could be fiable for a failure lo monitor, "only a sustained or systematic failure of the board lo exercise oversight-such as an utter failure lo attempt lo assure a reasonable information and reporting system exists will establish the lack of good faith that is a necessary condition lo liability.»

Condiciones de aplicación de la doctrina Caremark. «As the Stone Court explained: "Caremark articulates the necessary conditions predicate for director oversight liability: (a) the directors utterly failed lo implement any reporting or information system of controls; or (b) having implemented such a system or controls, consciously failed lo monitor or oversee its operations thus disabling themselves from being informed of risks or problems requiring their attention. In either case, imposition of liability requires a showing that the directors knew that they were not discharging their fiduciary obligations. Where directors fail lo act in the face of a known duty (or act, thereby demonstrating a conscious disregard for their responsibilities, they breach their duty of loyalty by failing lo discharge that fiduciary obligation in good faith). Thus, to establish oversight liability a plaintiff must show that the directors knew they were not discharging their fiduciary obligations or that the directors demonstrated a conscious disregard for their responsibilities such as by failing lo act in the face of a known duty lo act. The test is rooted in concepts of bad faith; indeed, a showing of bad faith is a necessary condition lo director oversight liability. Plaintiffs' Caremark Allegations Plaintiffs' theory of how the director defendants will face personal liability is a bit of a twist on ; the traditional Caremark claim. In a typical Caremark case, Plaintiffs argue that the defendants are fiable for damages that arise from a failure to properly monitor or oversee employee misconduct or violations of law. For example, in Caremark the board allegedly failed to monitor employee actions in violation of the federal AntiReferral Payments Law; in Stone, the directors were charged with a failure of oversight that resulted in liability for the company because of employee violations of the federal Bank Secrecy Act" ».

La regla del buen juicio empresarial. Su significado y condiciones para su aplicación. Relación entre el principio del buen juicio empresarial BJR y la tesis Caremark. La BJR no puede ser desplazada por la tesis Caremark. Compatibilidad entre ambas doctrinas: «The business judgment rule "is a presumption that in making a business decision the directors of a corporation acted on an informed oasis; in good faith and in the honest belief that the action taken was in the best interests of the company." The burden is on plaintiffs, the party challenging the directors' decision, lo rebut this presumption. Thus, absent an allegation of interestedness or disloyalty to the corporation, the business judgment rule prevents a judge or jury from second guessing director decisions if they were the product of a rational process and the directors availed themselves of all material and reasonably available information. The standard of director liability under the business judgment rule "is predicated upon concepts of gross negligence." Additionally, Citigroup has adopted a provision in its certificate of incorporation pursuant lo $8 \mathrm{Del}$. C. $\$ 102(b)(7)$ that exculpates directors from personal liability for violations of fiduciary duty, except for, among other things, breaches of 


\section{reconocimiento de la extensión y gravedad de los riesgos del negocio impli- cados en la actividad de la compañía en el mercado subprime caía de plano}

the duly of loyalty or actions or omissions not in good faith or that involve intentional misconduct or a knowing violation of law. Because the director defendants are "exculpated" from liability for certain conduct, 'then a serious threat of liability may only be found lo exist if the plaintiff pleads a non-exculpated claim against the directors based on particularized facts. '54 Here, plaintiffs have not alleged that the directors were interested in the transaction and instead root their theory of director personal liability in bad faith. The Delaware Supreme Court has stated that bad faith conduct may be found where a director "intentionally acts with a purpose other than that of advancing the best interests of the corporation, ... acts with the intent lo violate applicable positive law, or ... intentionally fails lo act in the face of a known duty lo act, demonstrating a conscious disregard for his duties." More recently, the Delaware Supreme Court held that when a plaintiff seeks lo show that demand is excused because directors face a substantial likelihood of liability where "directors are exculpated from liability except for claims based on fraudulent,' 'illegal' or 'bad faith' conduct, a plaintiff must also plead particularized facts that demonstrate that the directors acted with scienter, i.e., that they had 'actual or constructive knowledge' that their conduct was legally improper." The Delaware Supreme Court made clear in Stone that directors of Delaware corporations have certain responsibilities lo implement and monitor a system of oversight; however, this obligation does not eviscerate the core protections of the business judgement rule protections designed lo allow corporate managers and directors lo pursue risky transactions without the specter of being held personally liable if those decisions turn out poorly. Accordingly, the burden required for a plaintiff lo rebut the presumption of the business judgment rule by showing gross negligence is a difficult one, and the burden lo show bad faith is even higher. Additionally, as former-Chancellor Allen noted in Caremark, director liability based on the duty of oversight "is possibly the most difficult theory in corporation law upon which a plaintiff might hope lo win a judgment." The presumption of the business judgment rule, the protection of an exculpatory $\$ 102(h)(7)$ provision, and the difficulty of proving a Caremark claim together function lo place an extremely high burden on a plaintiff lo state a claim for personal director liability for a failure to see the extent of a company's business risk».

El riesgo es un elemento connatural a la decisión empresarial, y esta constatación elemental ha de tenerse presente al juzgar de la responsabilidad de los administradores. «To the extent the Court allows shareholder plaintiffs to succeed on a theory that a director is liable for a failure lo monitor business risk, the Court risks undermining the well settled policy of Delaware law by inviting Courts lo perform a hindsight evaluation of the reasonableness or prudence of directors' business decisions. Risk has been defined as the chance that a return on an investment will be different that expected. The essence of the business judgement of managers and directors is deciding how the company will evaluate the trade-off between risk and return. Businesses - and particularly financial institutions-make returns by taking on risk; a company or investor that is willing lo take on more risk can earn a higher return. Thus, in almost any business transaction, the panties go into the deal with the knowledge that, even if they have evaluated the situation correctly, the return could be different than they expected. It is almost impossible for a court, in hindsight, lo determine whether the directors of a company properly evaluated risk and thus made the "right" business decision. In any investment there is a chance that returns will turn out lower than expected, and generally a smaller chance that they will be far lower than expected. When investments turn out poorly, it is possible that the decision-maker evaluated the deal correctly but got "unlucky" 
dentro de la BJR. Añadía que alegar en estas condiciones la tesis Caremark suponía para los demandantes elegir una alternativa sin esperanza de vencer.

El mero hecho -dijo el Tribunal- de que una compañía asuma riesgos de negocio y sufra pérdidas -incluso pérdidas catastróficas- no evidencia una mala conducta y, por sí solo no autoriza a declarar la responsabilidad personal del Administrador... Los deberes de vigilancia en la ley de Delaware no han sido diseñados para someter a los administradores, incluso a administradores expertos, a responsabilidad personal por el hecho de fallar en la predicción del futuro y evaluar acertadamente los riesgos del negocio.

Los accionistas también alegaron que los miembros del Consejo habían provocado pérdidas a la compañía: (1) de 2,7 billones de dólares en préstamos subprime; (2) autorizando y no suspendiendo el programa de recompra de la compañía, al readquirir sus propias acciones de acuerdo con este a precios artificialmente inflados, con un quebranto resultante de 645 millones de dólares; (3) invirtiendo 7,9 billones de dólares en SIV, que al final resultaron incobrados y fallidos; y (4) aprobando un pago multimillonario como compensación por la salida o marcha del CEO, el presidente ejecutivo, Charles Prince.

El Tribunal rápidamente rechazó las demandas basadas en las pérdidas de la compañía. En cambio, declaró que la pretensión relativa a las compensaciones al CEO, que incluían 68 millones de dólares en salarios, bonos, acciones, pluses, un asistente administrativo, coche y chófer para cinco años, podían, si eran probados estos hechos, crear una duda razonable de que el convenio de cese fuese tan unilateral o descompensado, que excediera de lo que pudiera entenderse por un trato de negocio razonable y resultaba posible en tal caso que la sociedad o compañía no hubiera recibido de los jueces de instancia, al no atender esta reclamación, la consideración debida.

in that a huge loss the probability of which was very small actually happened. It is also possible that the decision-maker improperly evaluated the risk posed by an investment and that the company suffered large losses as a result. Business decision-makers must operate in the real world, with imperfect information, limited resources, and an uncertain future. To impose liability on directors for making a "wrong" business decision would cripple their ability to earn returns for investors by taking business risks. Indeed, this kind of judicial second guessing is what the business judgment rule was designed lo prevent, and even if a complaint is framed under a Caremark theory, this Court will not abandon such bedrock principles of Delaware fiduciary duty law. With these considerations and the difficult standard required to show director oversight liability in mind, I turn to an evaluation of he allegations in the Complaint». 
En fin, de la sentencia del tribunal se sigue que la BJR desempeña todavía un importante papel en la doctrina de este tribunal, y que el argumento Caremark presenta no pocos problemas y es de aplicación en contados casos, fundamentalmente en aquel en que se ha producido una sistemática y sustancial quiebra del Consejo en el ejercicio de su función de supervisión por no atender a información razonable y disponible o haber hecho caso omiso a los sistemas y protocolos existentes para tener acceso a dicha información.

La conclusión es que la doctrina Caremark tiene su ámbito de aplicación propio en el caso de comportamientos delictivos de los empleados, cuando han fallado negligente o dolosamente los sistemas de información de los administradores. Eso ocurre cuando «miran para otro lado», no atienden a las señales de alerta o red flags, o hacen caso omiso de los denunciantes de la empresa que obran movidos por el interés de la compañía (whistleblowers $)^{44}$.

\section{La regla del juicio de los negocios (o del buen juicio empresarial): 'Business Judgement Rule'}

La regla del buen juicio empresarial es creación de los tribunales norteamericanos. Ha de reconocerse que la contribución que ha resultado fundamental para modelar sus rasgos y condiciones de aplicación se debe a la Corte de Delaware. Sin embargo, antes de emprender su estudio, necesariamente somero, hay que insistir una vez más en su carácter proteico o variable. Esta regla no es una «norma» acabada, sino que se está haciendo cons-

\footnotetext{
${ }^{44}$ La bibliografía de esta rúbrica es extensa. Una selección esencialísima arroja el resultado siguiente: Bainbridge, Stephen M. «The Business Judgment Rule as Abstention Doctrine». 57 Van. L. Rev. 83 (2004). Branson, Douglas M. «The Rule that isn't a Rule- the Business Judgement Rule». Valparaíso University Law Review. Vol. 36, Año 2002, p. 631. Gentile, Mark J. y Christensen, Joseph L. «In re Citigroup: The Birth Announcement and Obituary of the Duty of Business Performance Oversight». Bloomberg Finance L.P. Vol 3, n. ${ }^{\circ}$ 19, edición de «The Bloomberg Law Reports-Corporate Law». Holger Fleischer, Ll. M. «La Business Judgement Rule a la luz de la comparación jurídica y de la economía del derecho». Revista de derecho mercantil. ISSN 0210-0797, N. ${ }^{\circ} 246,2002$, pp. 1727-1754. Lagualdo Giraldo, C. A. y Díaz Cañón, M. P. «Modern conception of business judgment rule. A case study on Delaware jurisprudence». International Law: Revista Colombiana De Derecho Internacional, Junio, Número 005. Pontífica Universidad Javeriana. Bogotá, Colombia. pp. 13-39. RADIN, Stephen A. «The Business Judgement Rules: Fiduciary Duties of Corporate Directors», agosto 2009. Ribstein, Larry E. y Alces, Kelli A. «The Business Judgement Rule in Good and Bad Times». Draft of October 17, 2005. Weiss, Paul. «Delaware Chancery Court in Disney affirms Business Judgment Rule deference; failure to abide by best practices not tantamount to fiduciary duty breach». In Re The Walt Disney Company Derivative Litigation, Del. Ch., C.A. N. ${ }^{\circ}$ 15452, August 9, 2005.
} 
tantemente. Es agua viva o corriente que se resiste a ser embotellada y a adquirir una formulación definitiva. Por eso, a lo largo del tiempo, ha ido adoptando diversas versiones ${ }^{45}$.

La BJR consiste en una presunción según la cual se considera que los administradores de la compañía, cuando adoptan una decisión empresarial, lo hacen sobre una base informada, de buena fe y con la creencia honesta de que la acción tomada redunda en interés de la sociedad. Mientras no se destruya esta presunción, que opera a modo de escudo jurídico protector de los administradores, los jueces ante los que se presenta una demanda de responsabilidad contra ellos no pueden entrar en el análisis del fondo de la actuación de los administradores, y han de respetar un ámbito de discrecionalidad. Más modernamente se ha determinado que la aplicación de la presunción requiere de una condición añadida: la racionalidad de la decisión. Pero solo cabe considerar irracional aquella decisión que sea tan manifiestamente imprudente que no pueda explicarse, en el sentido de que no se encuentre bien motivada y que ninguna persona mínimamente informada la hubiera tomado. Consecuentemente con ello la Corte de Delaware reconoce que no corresponde al Tribunal enjuiciar si los administradores adoptaron una decisión perfecta, sino una razonable. En otros términos: la judicatura no puede convertirse en una segunda instancia en el ejercicio de las funciones de administrador, comparando lo realmente decidido por los administradores con la decisión que hubiera resultado óptima en vista de la información generada con posterioridad a la decisión realmente adoptada y a las consecuencias que esta ha producido ${ }^{46 / 47}$.

${ }^{45}$ Seguimos la magnífica exposición de Hernando Cebriá. El deber de diligente administración en el marco de los deberes de los administradores sociales (La regla del -buen-juicio empresarial). Ed. Marcial Pons. Madrid, 2009, pp. 106-158.

${ }^{46}$ Unitrin Inc. Vs. American General Corp. 651 A.2d 1361 (Del. 1995).

${ }^{47}$ Sobre la actuación del «juez como administración de segunda instancia». Del mismo modo que no podemos exigir al juez, tomando a préstamo la metáfora de Dworkin, que sea sobrehumano, que sea un juez Hércules, tampoco podemos pretender que el administrador sea un Rey Midas, una garantía de ganancia segura, que convierte en oro todo lo que toca. La relación entre el juez y el administrador en el trance crítico de enjuiciamiento por aquel de la responsabilidad de este, da al primero una ventaja (vamos a denominarla «de laboratorio», porque permite analizar al primero los hechos enjuiciados con la tranquilitas del que considera un caso pasado) la actuación del segundo. El juicio, para ser simplemente honesto, ha de ser tal que prescinda matizadamente de todo lo sucedido con posterioridad a la acción enjuiciada, es decir, que despoje al juez de su «ventaja» de enjuiciamiento. La propuesta, en definitiva, sería algo semejante a la imagen que tan frecuentemente nos muestra la pantalla del jurado americano cuando el juez les dirige la admonición de que prescindan de una declaración u otra especie de prueba que ha sido traída indebidamente al proceso (lo que a mí, personalmente, nunca me ha parecido garantía suficiente de que vayan a hacerlo o a poder hacerlo). 
El ciclo vital de la BJR hasta ahora ha avanzado en forma de bucle. Partió restringiendo la responsabilidad de los administradores a los casos de negligencia grave y, después de algunas veleidades y matizaciones, retorna al punto de origen: solo una conducta gravemente irrazonable puede romper la coraza de la presunción. Ahora bien, ha de resultar claro por lo que va dicho que la mera alegación de honestidad o rectitud de intención no garantiza la inmunidad del administrador. La ignorancia o la inexperiencia, el «yo creía», no constituyen coartada. Es necesario, además, que se acredite competencia, dedicación y no desviación hacia asuntos o intereses particulares. Puede afirmarse, por lo tanto, que en la balanza de la responsabilidad y la discrecionalidad (authority v. accountancy) el argumento desequilibrante es la culpa grave. No fue así en una época intermedia, en que la negligencia simple resultaba bastante para privar a los administradores de la BJR. Junto al grado de la negligencia (leve, grave) que mide el nivel de aplicación de la BJR, otra consideración ha influido en la elección de las condiciones de aplicación del BJR y es si la diligencia exigible al administrador ha de ceñirse a la que hace referencia al cumplimiento de las reglas procedimentales y protocolos en la adopción de las decisiones, o ha de alcanzar también a la decisión de fondo por ellos adoptada. Esta es una cuestión que ha planteado cierto debate en la doctrina americana, pero la posición jurisdiccional al día de hoy resulta inequívoca: también se exige la diligencia respecto de los aspectos materiales de la decisión.

En conexión con lo anterior cabe plantearse si el nivel de diligencia requerido legal o judicialmente a los administradores puede ser elevado estatutariamente. Ciertamente, no debe quedar duda de la imposibilidad contraria. La regla no es derecho dispositivo que permita rebajar la exigencia; pero, asimétricamente, puede ser de derecho voluntario en cuanto se venga a reforzar o elevar el grado de la diligencia requerida ${ }^{48}$.

Repárese, por otra parte, en que la evolución histórica de la BJR, posibilitada por construirse el principio con material de evidente ductilidad (los conceptos jurídicos indeterminados) atribuye al juez una función de «regulador del caudal». Él es dueño de la llave de paso, lo que permite atemperar la exigencia de responsabilidad tanto a las circunstancias del caso concreto como a consideraciones macroeconómicas, sociales o culturales.

Un aspecto al que se ha prestado gran atención en la literatura especializada norteamericana es el relativo al fundamento del privilegio BJR. Los

\footnotetext{
${ }^{48}$ Salvando las evidentes diferencias, el caso recordaría al diseño de la relación entre las competencias normativas, articuladas telescópicamente (bases-normas de desarrollo), atribuidas entre nosotros al Estado y a las comunidades autónomas en materia de protección del medio ambiente; las autonomías pueden establecer reglas adicionales de protección (art. 149.1.23. ${ }^{a}$ ), pero, cabe añadir, no relajar las estatales, que constituyen el nivel mínimo e irreducible.
} 
autores lo han encontrado en la función económica que cumple; función que tiene varias manifestaciones:

a) En primer lugar, es inherente a los administradores la asunción de riesgos. En esto consiste en gran medida su trabajo. Es más, al menos en las grandes compañías cotizadas es frecuente que exista una demanda de los inversores en el sentido de que no se eludan sistemáticamente tales riesgos (y, ciertamente, las posibilidades de ganancias que ellos entrañan). El fundamento del contrato societario, la base o causa, es la obtención del lucro (de lucro partible según resulta del art. 1665 de nuestro Código Civil) y ello obliga a afrontar riesgos. Por ello no es el mejor administrador el que se ciñe a realizar un proyecto estrictamente conservativo de un patrimonio, dejándose guiar por una aversión radical al riesgo (de nuevo la parábola evangélica de los talentos resulta en este punto pedagógica). Un tribunal que, al enjuiciar eventuales responsabilidades de los administradores, constriñera su examen a comprobar si el administrador actuó con «prudencia» no contribuye a fomentar un modelo de buen administrador ${ }^{49}$. Ciertamente, este primer argu-

\footnotetext{
${ }^{49}$ A estos efectos, cabe traer a colación, por su valor paradigmático de lo que estamos diciendo, la Sentencia de 11 de mayo de 1991 del Tribunal Supremo (Sala de lo Civil), R.J. $3627 / 1991$ hace una interesante declaración en relación con la prudencia de los gestores (si bien en este caso se trataba de la responsabilidad del Gerente, no de los administradores). Previamente confirma el criterio de la sentencia de apelación acerca de la innecesariedad de demandar junto al gerente a los administradores: «...la sentencia recurrida no considera que debían haber sido parte en el proceso entablado los miembros del Consejo de Administración de la entidad de que era Gerente el demandado D. José María G. M., como tampoco el objeto social, su tráfico mercantil, actividad de dicho demandado, facultades y cuantías de las operaciones atribuidas a aquel, de una parte debido a que siendo la responsabilidad atribuible al mencionado gerente de la entidad Papelera San José S. A. inherente al ejercicio de su actividad en el desempeño de tal cargo, es a él exclusivamente a quien procedía demandar y no a los miembros del Consejo de Administración que no tienen como cometido el desarrollar las funciones de gerencia...». Después de la precedente depuración sobre la persona responsable aborda la «cuestión de la prudencia» en los siguientes términos: «...como certeramente se indica en la sentencia recurrida, el tráfico normal de la empresa Papelera San José S. A., su objeto social y facultades del Gerente demandado, ahora recurrente, D. José María G. M., no posibilitaban la realización de operaciones tan aventuradas como las de comprar a la entidad Gexpa S. A., cuando estaba próxima a suspensión de pagos, partidas de papel por alto valor económico, que tal entidad suministrada no abonó, y entregar asimismo a la referida Gexpa $S$. A., igualmente con proximidad a su suspensión de pagos, una elevada cantidad de dinero a cuenta de diversos suministros de pasta que debía efectuar, lo cual no se hizo, aceptando el mencionado Gerente cambiarlos por valor de la suma entregada, no reintegrada por consecuencia de dicha suspensión de pagos, puesto que esa actividad es reveladora, lógicamente, de una actividad negligente grave que ciertamente no puede entenderse justificada por el tráfico y objeto social de la precitada entidad Papelera San José S. A. y facultades del expresado Gerente, que normalmente impedían, precisamente por dicho tráfico y objeto social y facultades, el no llevar a cabo operaciones de tal naturaleza, y sin adecuadas garantías, a entidad que estaba próxima a suspensión de pagos, generando un comportamiento negligente grave, como pone de manifiesto perito
} 
mento en pro de la BJR es aplicable a las grandes sociedades cotizadas (en las que los accionistas inversores pueden resultar neutrales ante el riesgo porque han diversificado estratégicamente sus carteras), pero no puede ser trasladado a compañías de menor tamaño.

b) La existencia de un mercado de directivos y administradores, que valora positivamente el prestigio y realizaciones de los sujetos que forman parte de él, ya constituye suficiente motivación para que los administradores se esmeren en el logro de resultados positivos; es decir, en una gestión óptima de los riesgos. A esto se ha aludido anteriormente en el presente trabajo al plantear la propuesta de Paz-Ares sobre la estratificación de la regulación de los deberes de los administradores.

c) Otra función de la regla consiste en favorecer la incorporación a los órganos de administración de aquellas personas más aptas o que reúnen mejores condiciones, a las que una política rigurosa de responsabilidad acabaría apartando o disuadiendo. Porque la alternativa, económicamente costosa, para garantizar esa selección de los mejores, en el caso de mantenerse una regla de responsabilidad severa, consistiría en desplazar la responsabilidad a las compañías aseguradoras o en abonar a los propios administradores una prima complementaria por riesgos de responsabilidad asumidos, lo cual sigue siendo económicamente ineficiente.

d) El respeto al ámbito competencial. «Abaratar» en términos jurídicos la posibilidad de exigir responsabilidades a los administradores puede conducir a que los accionistas chantajistas, manteniendo una sistemática presión sobre los administradores con amenaza de indiscriminadas demandas, puedan doblegar la voluntad de los gestores y desviarla del fin social, con daño para los demás socios que no participan en la maniobra. Ha de asegurarse a los administradores la posibilidad de desempeñar su tarea sin este tipo de condicionamientos; es decir, ha de respetarse su ámbito competencial.

Hay, además de las ya consignadas, otras razones, de corte no estrictamente económico. Los jueces no pueden ejercer, por falta de preparación, una revisión completa de la actuación de los administradores. Ellos son técnicos en Derecho, no «administradores en segunda instancia». En este sentido cabe recordar el peligro que entraña la revisión a posteriori de la decisión judicial (hindsight bias), pues el control judicial no puede reproducir las condiciones reales en que se adoptó la decisión del administrador cuestionada y enjuiciada: imponderables, intuiciones, información disponible desconocidamente sesgada, etc.

informante en autos cuando indica que, con dichas apreciaciones, a tenor del diferencial obtenido y el factor riesgo asumido, desde un principio de prudencia, que debe dominar toda gestión empresarial, la operación de aprovisionamiento no respondía satisfactoriamente a las condiciones de compra óptimas, y sin que ello venga justificado por las amplias facultades que fueron conferidas al mencionado gestor, pues esa amplitud no son base para actuar ejerciéndolas de forma negligentemente grave». 
De la doctrina jurisprudencial resulta que el administrador que pretende el abrigo de la BJR ha de acreditar que concurren las condiciones de su aplicación que inmediatamente recordaremos. Si consigue probar tales requisitos, el juez no puede continuar en el análisis de la responsabilidad, porque ha topado con un blindaje impenetrable. Su interior constituye el ámbito de la discrecionalidad administrativa (de los administradores, quiere decirse). Tales condiciones son las siguientes:

I) Que el administrador no haya adoptado una decisión contraria a la ley ni a los estatutos.

II) Que haya actuado con lealtad e independencia de sus intereses particulares. Es decir, que no busque un beneficio personal que desplace al de la sociedad $^{50}$ (entire fairness standard of review). Pero la deslealtad también se aprecia cuando la actuación en interés de terceros prevalece sobre el interés social.

III) Buena fe o fidelidad al interés social. La decisión ha de cumplir dos premisas básicas para que el administrador quede protegido por la BJR: (1) materialmente, la decisión o actuación ha de integrarse en el objeto social o actividad propia de la compañía; (2) la orientación final de la actuación ha de ser la de maximizar, inmediata o mediatamente, el valor total de la sociedad.

Esta condición obliga al administrador que impetra la regla del buen juicio empresarial a dar alguna explicación acerca de lo razonable de su actuación y que esta sea conveniente para el interés social. Por ello, decisiones que obedecen a motivaciones espurias, tales como venganzas, odios personales, envidias, donaciones ilegales a partidos políticos, etc. ${ }^{51}$, no superarían el escrutinio del BJR.

El cumplimiento de buena fe del interés social hay que entenderlo objetiva, no subjetivamente. No consiste en la creencia de que se perseguía el bien de la sociedad, o la ignorancia de que el administrador se estaba apartando de él. En el juicio, demandante y administradores demandados deberán acreditar lo que a su respectiva posición interese, pero teniendo en cuenta el principio de facilidad de prueba. Y a este respecto hay que reconocer la ventaja, la mayor disposición de medios probatorios con que cuentan los administradores, que por eso son insiders. El prestigio o el valor reputacional

\footnotetext{
${ }^{50}$ Nuestro Código Civil, de 1889, ya reaccionaba frente a un caso de deslealtad del socio, entendida como priorización de sus intereses frente a los de la sociedad. Después de señalar su art. 1.705 que la disolución de la sociedad por la voluntad o renuncia de uno de los socios será posible cuando no se ha señalado plazo para su duración, o no resulte este de la naturaleza del negocio, exige, para que la renuncia surta efecto, que se haga de buena fe, en tiempo oportuno y poniéndola en conocimiento de los demás socios. Pero el art. 1.706, primer párrafo, primer inciso, dispone que «es de mala fe la renuncia cuando el que la hace se propone apropiarse para si solo el provecho que debía ser común»

${ }^{51}$ Branson, op. cit., p. 642.
} 
constituye una posible justificación de que la actuación de los administradores se dirigía a servir los intereses sociales» ${ }^{52}$.

Es contraria a la exigencia de la buena fe y constituye una desviación del interés social el derroche de bienes sociales, la enajenación de activos por debajo del precio de mercado e incurrir en gastos que no se orienten a la inversión u obedezcan a las necesidades de la actividad empresarial. Esta concreta forma de incumplimiento del deber de buena fe ha sido debidamente formulada como doctrina del corporate waste.

IV) Los administradores han de actuar sobre una base informada, lo que significa que han de verificar todos los datos e informes que tengan a su alcance y, además, los que razonablemente hubieran de recabar. En la práctica esta condición de actuar debidamente informados ha llevado a los administradores a solicitar asesoramiento de expertos externos, no solo con el propósito de «mejorar» sus decisiones, sino también de acorazarse frente a posibles reclamaciones de responsabilidad.

Cumplidos todos los anteriores requisitos de aplicación, el principio BJR hace las veces de un puerto seguro (safe harbour), que impide progresar la acción de responsabilidad contra los administradores.

\section{El caso y la decisión 'Caremark'53}

La cuestión litigiosa puede exponerse como sigue. Caremark era entonces -y sigue siéndolo hoy- una gran compañía de Delaware, con más de 7000 empleados y noventa sucursales, que cotiza en la Bolsa de Nueva York y presta servicios varios en el área de la salud, tanto de índole médica como farmacéutica, algunos de ellos de coste elevado: terapia de la hormona de crecimiento, de VIH/SIDA, hemofilia, etc. La Anti-Referral Payments Law (ARPL) prohibió, bajo amenaza de severísimas sanciones, atraer a pacientes cubiertos por los sistemas públicos de la salud (limitados, como es sabido por las noticias que los medios han divulgado hace pocas semanas sobre la

${ }^{52}$ Hernando Cebriá, L. Op. cit., recoge en p. 143, nota 116, una referencia a la Sentencia del caso Shlensky vs. Wrigley [237 N.E.2d 776 (III. App. 1968)] que no me resisto a dejar de transcribir. Se trataba de la instalación de luz en un estadio de béisbol para poder jugar de noche y aumentar así el aforo. Los administradores no se hicieron eco de esta propuesta, justificando su decisión en que tendría un impacto negativo en el vecindario y en que no afectaba la iniciativa sustancialmente a la maximización del valor de la sociedad. El Tribunal declaró que siempre que los administradores actúen dentro de los límites de la ley gozan de libertad para decidir acerca de la gestión de la sociedad: «In a purely business corporation... The authority of the directors in the conduct of the business of the corporation must be regarded as absolute when they act within the law, and the court is without authority to substitute its judgment for that of the directors».

${ }^{53}$ In re Caremark International Inc. Derivative Litigation. Court of Chancery of Delaware, 25 septiembre 1996. Civil action n. 13670. 
propuesta del presidente Obama de ampliar su ámbito de cobertura), allí confiados a Medicare y Medicaid (respectivamente, para personas mayores de 65 años y para las que carecen de recursos), cuando los procedimientos de captación de estos pacientes del sistema público se basaran en los pagos o cualesquiera otras formas de remuneración a los prescriptores (médicos, hospitales, etc.) que «canalizaran» la clientela. Ante la sospecha de que Caremark estaba involucrada en este tipo de actividades ilícitas, consistentes en hacer pagos a «proveedores» de clientes, el Departamento de Salud y Servicios Humanos y el de Justicia emprendieron una intensa investigación que se prolongó por más de cuatro años. En 1994 Caremark fue acusada formalmente de la comisión de varios delitos. El proceso concluyó con la firma de un convenio en que la compañía admitía responsabilidades penales menores (se declaró responsable de un delito de fraude electrónico) y se obligó a pagar una serie de multas penales e indemnizaciones. El coste total de este compromiso ascendió a 250 millones de dólares. En el mismo año 1994, cuando el pago de ese importe se hubo realizado, un grupo de accionistas presentó una demanda de responsabilidad social contra los administradores (derivative claim). La decisión del tribunal consistió en la aprobación de un acuerdo de transacción entre demandantes y demandados, acuerdo que contemplaba, además, la adopción para el futuro por Caremark de un protocolo de vigilancia interna para que no se repitieran en lo sucesivo las malas prácticas. La ponente de la decisión, la magistrada o canciller Allen no se conformó, sin embargo, con dar la aprobación al convenio transaccional, sino que añadió una serie de consideraciones que analizaron cuál era la responsabilidad de los administradores en el caso de defecto en el cumplimiento de la función de supervisión que les corresponde y la doctrina que recayó desde entonces se ha convertido en precedente muchas veces invocado. Sería algo así como lo que entre nosotros se conoce con la expresión «doctrina legal» (del Tribunal Supremo). En estas consideraciones complementarias se constata, en primer lugar, que Caremark no se había conducido con dejadez en el ejercicio de la función de vigilancia, pues contaba con un plan de auditoría interna para asegurar el cumplimiento de principios éticos; la firma Price Waterhouse prestaba el servicio de auditoría externa (y en 1993 había presentado un extenso informe en el que concluía que no había deficiencias sustanciales en los sistemas de control de Caremark); se había establecido un Comité de Ética delegado del Consejo de Administración; se procuraba formación ética y de las obligaciones derivadas de la ARPL a los comerciales de la compañía; incluso se había elaborado un manual de comportamiento ético; y, en fin, se había mandado circulares a los empleados con la obligación que tenían de comunicar a un número de teléfono gratuito y confidencial-«ética línea directa»-todas las conductas ilegales internas que llegaran a su conocimiento.

A pesar de las anteriores cautelas, el 4 de agosto de 1994 un jurado federal de Minnesota acusó a la compañía de violar la ARPL. Según la acusa- 
ción, más de 1,1 millones de dólares habían sido pagados a un médico practicante de Mineápolis, David R. Brown, para inducirlo a distribuir Protropin, una hormona de crecimiento humana comercializada por Caremark. Parte de los pagos que se le hicieron figuraban registrados como becas de investigación, otra parte como contratos de consultoría. Además, se acreditó que el médico recibió de Caremark otros beneficios: el pago de los gastos de personal y oficina, incluidos los servicios de contestador telefónico, fax y alquiler del local.

La demanda de responsabilidad social alegaba que los administradores demandados habían incumplido su deber de diligencia al no haber supervisado de manera suficiente la conducta de sus empleados (en definitiva, aducía lo que nosotros denominamos culpa in vigilando), ni haber establecido medidas correctoras adecuadas, exponiendo con ello a la compañía a multas y responsabilidades.

Allen, al analizar la demanda, distingue dos situaciones en que puede plantearse la cuestión de la responsabilidad de los administradores: primera, derivada de la toma de decisiones; segunda, la responsabilidad por déficit de seguimiento o supervisión.

En el primer caso, procede aplicar la regla del buen juicio empresarial. No es exigible la responsabilidad si los administradores han actuado de buena fe, se han preocupado diligentemente de contar con la información adecuada y disponible y su intervención no ha sido claramente irracional. Y añade Allen que si un juez, al entender del asunto, considera que la decisión de los administradores a la postre se había revelado estúpida, sigue sin haber fundamento para declarar su responsabilidad, siempre que se cumplan las condiciones de buena fe, cuidado en la información y ausencia de irracionalidad ostensible ${ }^{54}$.

${ }^{54}$ Dice la decisión de la Corte en lo relativo a la primera posible causa de responsabilidad. «1. Potential liability for directorial decisions: Director liability for a breach of the duty to exercise appropriate attention may, in theory, arise in two distinct contexts. First, such liability may be said to follow from a board decision that results in a loss because that decision was ill advised or "negligent". Second, liability to the corporation for a loss may be said to arise from an unconsidered failure of the board to act in circumstances in which due attention would, arguably, have prevented the loss. See generally Veasey \& Seitz, The Business Judgement Rule in the Revised Model Act. 63 TEXAS L.REV. 1483 (1985). The first class of cases will typically be subject to review under the director-protective business judgement rule, assuming the decision made was the product of a process that was either deliberately considered in good faith or was otherwise rational. See Aronson v. Lewis, Del. Supr., 473 A.2d 805 (1984); Gagliardi Y. TriFoods Int'1, Inc., Del. Ch., 683 A.2d 1049 (1996). What should be understood, but may not widely be understood by courts or commentators who are not often required to face such questions, $\left.{ }^{15}\right]$ is that compliance with a director's duty of care can never appropriately be judicially determined by reference to the content of the board decision that leads to a corporate loss, apart from consideration of the good faith or rationality of the process employed. That is, whether a judge or jury considering the matter after the fact, believes a decision substantively wrong, or degrees of wrong 
El cuanto al segundo supuesto, el de la falta de la vigilancia exigible, declara Allen que ha tenido una importancia creciente en los últimos tiempo de la mano de la legislación penal que trata de garantizar el respeto al medio ambiente, la seguridad de los productos y la salud y seguridad laborales. Esta legislación contiene importantes incentivos, en forma de causas de exoneración o atenuación de las responsabilidades, para las empresas que adoptan medidas con el fin de detectar las violaciones de la ley, evitarlas y corregirlas en el caso de que finalmente se hayan producido. Y entra por fin más adelante en el examen del caso concreto que es objeto del litigio, al declarar que, en general, cuando una demanda de responsabilidad por pérdidas sociales frente a los administradores se basa en la ignorancia de estos respecto de las actividades y prácticas que tenían lugar dentro de la propia compañía o realizaban sus empleados, solo un fracaso constante y sistemático del consejo de administradores al tratar de asegurar que se va a contar con la información razonable podrá permitir apreciar la ausencia de buena fe, que es la condición fundamental sobre la que pivota la declaración de responsabilidad. Este test de responsabilidad -la falta de buena fe evidenciada por sostenidos o sistemáticos fallos de los administradores en el ejercicio de una razonable

extending through "stupid", to "egregious" or "irrational", provides no ground for director liability, so long as the court determines that the process employed was either rational or employed in a good faith effort to advance corporate interests. To employ a different rule -one that permitted an "objective" evaluation of the decision-would expose directors to substantive second guessing by ill-equipped judges or juries, which would, in the long-run, be injurious to investor interests. ${ }^{16}$ Thus, the business judgment rule is process oriented and informed by a deep respect for all good faith board decisions.

Indeed, one wonders on what moral basis might shareholders attack a good faith business decision of a director as "unreasonable" or "irrational". Where a director in fact exercises a good faith effort to be informed and to exercise appropriate judgment, he or she should be deemed to satisfy fully the duty of attention. If the shareholders thought themselves entitled to some other quality of judgment than such a director produces in the good faith exercise of the powers of office, then the shareholders should have elected other directors. Judge Learned Hand made the point rather better than can 1. In speaking of the passive director defendant Mr. Andrews in Barnes v. Andrews, Judge Hand said:

True, he was not very suited by experience for the job he had undertaken, but 1 cannot hold him on that account. After all it is the same corporation that chose him that now seeks to charge him... Directors are not specialists like lawyers or doctors... They are the general advisors of the business and if they faithfully give such ability as they have to their charge, it would not be lawful to hold them liable. Must a director guarantee that his judgment is good? Can a shareholder call him to account for deficiencies that their votes assured him did not disqualify him for his office? While he may not have been the Cromwell for that Civil War, Andrews did not engage to play any such role.

In this formulation Learned Hand correctly identifies, in my opinion, the core element of any corporate law duty of care inquiry: whether there was good faith effort to be informed and exercise judgment. 
vigilancia-, añadía la ponente, posiblemente resulte beneficioso para los accionistas y estimule la buena fe de los propios administradores ${ }^{55}$.

\section{Continuará}

Este trabajo consta de dos tiempos. Agotado el primero, conviene adelantar una idea de por dónde ha de discurrir el que resta. Ciertamente, se trata de una convicción más que intuitiva de la idea de que el campo material de lo económico-financiero se presenta como uno de los más aptos para verificar la globalización de la ley. Per se constituye un ámbito que contiene una tendencia congénita a la expansión internacional. Como una marea incontenible acaba inundando la totalidad del mundo; es imposible poner puertas a este campo. La ley (accesorium sequitur principale) ha de correr la misma suerte. Tal uniformidad normativa no opera de la noche a la mañana. Se basa, desde luego, en la imitación, y aquí el modelo a seguir es el de la economía más fuerte, la americana y, por ello, el Derecho de referencia es en gran medida el americano también. Lo que resta entonces por hacer, y ello constituirá el objeto de la segunda parte de este trabajo, que no puede finalizar

${ }^{55}$ Declaraba la Corte a este respecto lo siguiente: «2. Failure to monitor: Since it does appears that the Board was to some extent unaware of the activities that led to liability, 1 turn to a consideration of the other potential avenue to director liability that the pleadings take: director inattention or "negligence". Generally where a claim of directorial liability for corporate loss is predicated upon ignorance of liability creating activities within the corporation, as in Graham or in this case, in my opinion only a sustained or systematic failure of the board to exercise oversight-such as an utter failure to attempt to assure a reasonable information and reporting system exits-will establish the lack of good faith that is a necessary condition to liability. Such a test of liability -lack of good faith as evidenced by sustained or systematic failure of a director to exercise reasonable oversight-is quite high. But, a demanding test of liability in the oversight context is probably beneficial to corporate shareholders as a class, as it is in the board decision context, since it makes board service by qualified persons more likely, while continuing to act as a stimulus to good faith performance of duty by such directors.

Here the record supplies essentially no evidence that the director defendants were guilty of a sustained failure to exercise their oversight function. To the contrary, insofar as 1 am able to tell on this record, the corporation's information systems appear to have represented a good faith attempt to be informed of relevant facts. If the directors did not know the specifics of the activities that lead to the indictments, they cannot be faulted.

The liability that eventuated in this instance was huge. But the fact that it resulted from a violation of criminal law alone does not create a breach of fiduciary duty by directors. The record at this stage does not support the conclusion that the defendants either lacked good faith in the exercise of their monitoring responsibilities or conscientiously permitted a known violation of law by the corporation to occur. The claims asserted against them must be viewed at this stage as extremely weak». 
con unas «conclusiones», sino con el suspense del «continuará», consiste, propiamente en lo siguiente:

a) Analizar si el modelo americano de la responsabilidad de los administradores es aprovechable en nuestro Derecho. Aún más, si de manera más o menos directa, no sucede ya que ese modelo ha inspirado nuestro régimen legal en este punto; o, al menos, si surgen dudas sobre su verdadero origen, no se advierten entre ambos ordenamientos muchos elementos de coincidencia. Y ello habrá de verificarse escapando de tentaciones voluntaristas que llevan a apreciar similitudes donde solo puede verlas quien realmente desea hacerlo, forzando la realidad de las cosas.

La convergencia entre los distintos modelos legales podría significar que también el Derecho de Sociedades está sujeto a un proceso semejante al de la paulatina elaboración de una normativa internacional que, como ocurrió con la Lex mercatoria en la Baja Edad Media, permite pronosticar la paulatina formación por sedimentación de un nuevo Derecho de Sociedades internacional. Los principios de actuación serán costumbre en una segunda fase $y$, al final del proceso, Derecho positivo.

b) Si se constata el parentesco de los dos sistemas, procederá a continuación examinar si la base experiencial americana, que se expresa en la doctrina de una jurisdicción singularmente competente y eficiente en este ámbito del Derecho de Sociedades, es o no trasladable a nuestro caso. La oportunidad de esta reflexión viene avalada por el hecho de que nuestra jurisprudencia en la materia, sobre todo en lo relativo al incumplimiento del deber de lealtad que sujeta a los administradores, es singularmente pobre, y tal vez de la experiencia ajena se puedan obtener algunas provechosas enseñanzas. La «aplicación analógica de la doctrina jurisprudencial extranjera», si no podrá apelar a un argumento de autoridad como es el que resulta de la «identidad de razón» (art. 4.1 del Código Civil), según la consideración de que aquí no estamos haciendo referencia a la «extensión» de normas sino de decisiones judiciales, contará con la no desdeñable fuerza del sentido común, de la racionalidad. Y con todas las cautelas (ya decía de la analogía legis Laun que se trataba de un mecanismo sutil y arriesgado en la aplicación del Derecho, que había que utilizar con sumo cuidado, «pues de un gancho pintado en la pared solo puede colgarse un gabán pintado en la pared») podría analizarse en qué casos resulta indicado adoptar entre soluciones procedentes de la práctica norteamericana.

c) Por último, a la luz de la experiencia judicial americana, de nuestra legislación y de nuestra jurisprudencia, cabe plantearse el reto de tratar de «domesticar» los concepto vagos con que la norma delinea las obligaciones inherentes de los administradores: diligencia de un ordenado empresario y un representante leal; fidelidad al interés de la sociedad; lealtad. Son términos lo bastante abiertos como para intimidar al agente, al administrador, pues en su perímetro caben posibilidades muy diversas. ¿Será posible reducir los márgenes de incertidumbre que sugieren esos términos open texture, afinar 
su significado para hacer más previsibles las condiciones de su aplicación, a fin de que el administrador pueda asociar con alguna seguridad la respuesta judicial probable en relación con sus iniciativas de decisión o de acción? ¿O quedará condenado a soportar una justicia errática que, como en los juegos de azar, puede depararle cualquier resultado y habrá de aprender a gestionar ese «riesgo de responsabilidad» apelando a instrumentos como el seguro de -cuyo coste trasladará, probablemente, a la compañía-, la huida del peligro, etc.? De suceder esto último se produciría una situación similar a la que Napoleón aconsejaba: gobierna a tu pueblo con tantas leyes que nadie sepa en ningún momento si puede estar incumpliendo alguna.

En fin, que continuará... Hasta entonces, si hubiera algún administrador societario entre los lectores de este artículo (tal vez esto puede parecer presuntuoso, así que dejémoslo en «si hubiera alguien», administrador o no, que haya sentido la curiosidad suficiente), tendrá que hacer acopio de paciencia para enfrentarse a los interrogantes que sobre la medida de la responsabilidad por la gestión arroja nuestro ordenamiento. 